\title{
PERFORMANCE EVALUATION OF IN-SERVICE, ELEVATED \\ TEMPERATURE INDUSTRIAL INSULATION
}

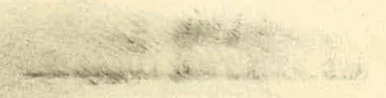

By

Dennis J. Martin

December 18,1978

\section{MASTER}

Work Performed Under Contract No. EC-77-C-02-4095

York Research Corporation

Stamford, Connecticut

\section{U. S. DEPARTMENT OF ENERGY}

Division of Industrial Energy Conservation 


\section{DISCLAIMER}

This report was prepared as an account of work sponsored by an agency of the United States Government. Neither the United States Government nor any agency Thereof, nor any of their employees, makes any warranty, express or implied, or assumes any legal liability or responsibility for the accuracy, completeness, or usefulness of any information, apparatus, product, or process disclosed, or represents that its use would not infringe privately owned rights. Reference herein to any specific commercial product, process, or service by trade name, trademark, manufacturer, or otherwise does not necessarily constitute or imply its endorsement, recommendation, or favoring by the United States Government or any agency thereof. The views and opinions of authors expressed herein do not necessarily state or reflect those of the United States Government or any agency thereof. 


\section{DISCLAIMER}

Portions of this document may be illegible in electronic image products. Images are produced from the best available original document. 


\section{DISCLAIMER}

"This book was prepared as an account of work sponsored by an agency of the United States Government. Neither the Uniled Statcs Government nor any agency thereof, nor any of their employees, makes any warranty, express or implied, or assumes any legal liability or responsibility for the accuracy. completeness, or usefulness of any information, apparatus, pivilucl, vi process disclosed, or represents that its use would not infringe privately owned rights. Reference herein to any specific commercial product, process, or service by trade name, trademark, manufacturer, or otherwise, does not necessarily constitute or imply its endorsement, recommendation, or favoring by the United States Government or any agency thereof. The views and opinions of authors expressed herein do not necessarily state or reflect those of the United States Government or any agency thereof."

This report has been reproduced directly from the best availablc copy.

Available from the National Technical Information Service, U. S. Department of Commerce, Springfield, Virginia 22161.

Price: Paper Copy $\$ 8.00$

Microfiche $\$ 3.50$ 


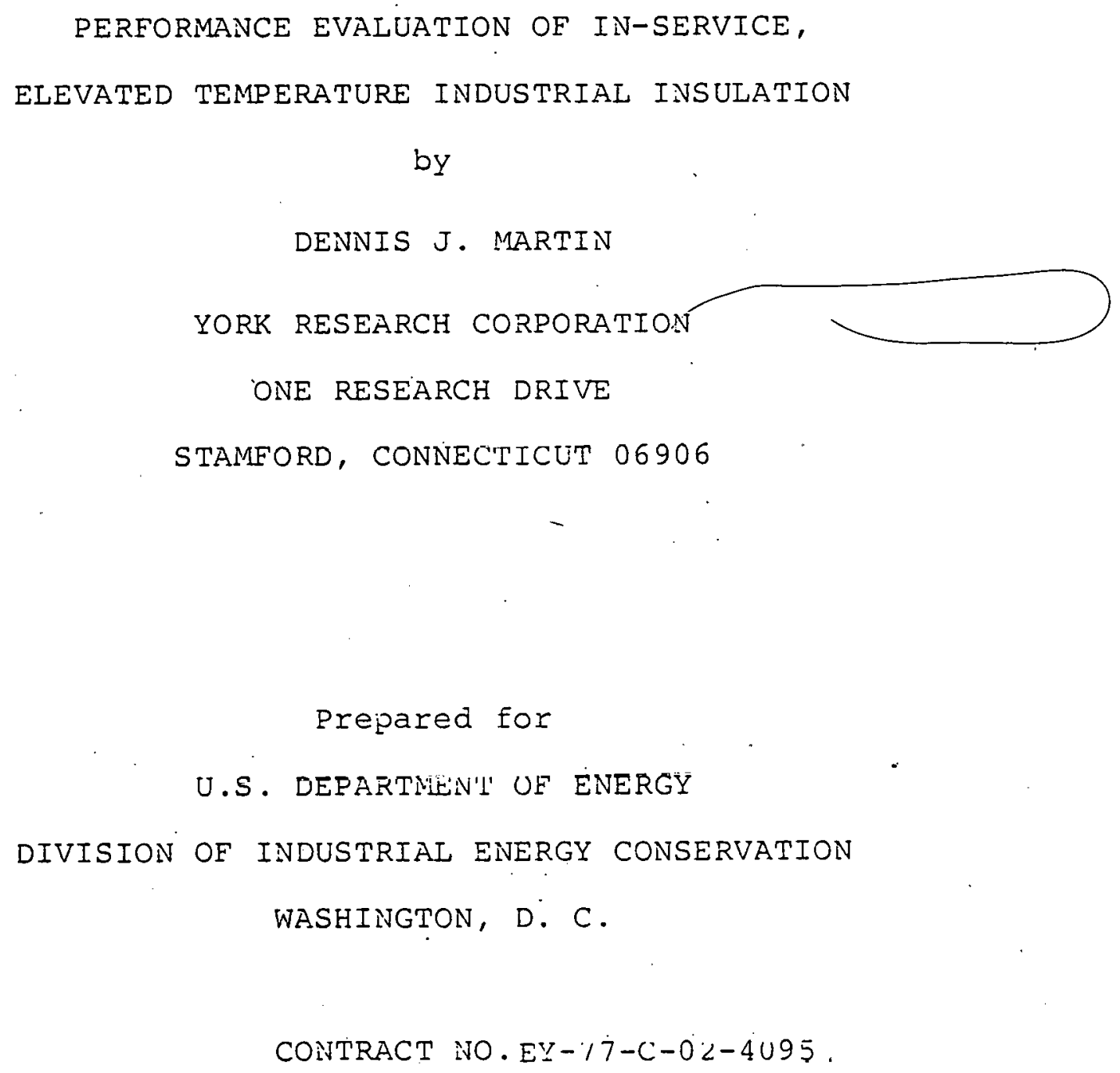




\section{TABLE OF CONTENTS}

ACKNOWLEDGEMENTS

ABSTRACT

1.0 SUMMARY

2.0 RECOMMENDATIONS

3.0 INTRODUCTION

3.1 General

3.2 Objectives

4.0 APPROACH AND METHODOLOGY

4.1 Appriati

$4 . \dot{2}$ : Methodologies.

4.2.1 Expected thermal conductivity values

4.2..2 Heat flow

4.2.3. Temperature measurement

4.2 .4 Other:measurements

4.3 Overview of :Field Measurement procedures

5.0 RESULTS

5.1 General

5.2 "Calibration Results

5.2.1 Pipe insulation instrument

5.2 .2 Heat \pm 1 ow meters

5.2.3 Temperature measurements

5.3 Field Results

5.4 Statistical Analyses

5.4.1 Test for significant difference

5.4.2 Analysis of variance

5.4 .3 Regréssion analysis

5.5 Moisture Results

6.0 CONCLUSTONS

6.1 Overview

6.3 Digcusainn

7.0 REFERENCES

APPENDIX A - Report By Sparrell Engineering on Thermal Conductivity Instrument

APPENDIX B - Report BY Oak Ridge National Laboratory on Pipe Tester Calculations with HEATINGS 


\section{ACKNOWLEDGEMENTS.}

This report has been submitted in fulfillment of the requirements under DOE Contract No. EY-77-C-02-4095. The author wishes to thank Dr. Gail Garbarine of the Department of Energy for her help and patience during a long and difficult program and Dr. Dave MCElroy for his comments and suggestions. Appreciation is also extended to Dr. Marilynn S. Decker of the University of connecticut in stamford for her assistance in the analysis of the data. Also recognition is made of Messers. William Goodrich, William Grubel and Alan Lampert who collected the field and laboratory data. 


\section{ABSTRACT}

A purchaser of industrial insulation is concerned with many factors which bear on the type of insulation selected. One of the most important factors, undoubtedly, is the thermal conductivity. The thermal conductivity is a measure of the ability of an insulation to conduct heat. The lower this value the better the insulation appears to the buyer. In the past it was generally assumed that the conductivity during the life of the insulation could be taken as a fixed property so lonq as external influences such as moisture or physical damage do not occur. Due to the dramatic increase in the cost and availability of energy in recent years, investigation of the validity of this long-standing assumption is in order. The purpose of this study was to determine whether deterioration of industrial insulation does occur and, if so, attempt to identify the reasons. In order to accomplish this, it was" necessary to first develop methods by which the conductivity could be determined in the field. Once this was accomplished, a field test program was implemented. It was determined from this program that there was a significant difference between the conductivity values obtained and those which were expected from manufacturer's data. However, this variation was not attributable to any of the factors investigated and could be due to either inherent measurement inaccuracies or the tendency of manufacturers' data to overestimate pertormance. 


\subsection{SUMMARY}

This repcrt deals with the result of an investigation into possibie degradation of industrial thermal insulation. Three types of insulation were investigated; namely, calcium silicate, fiber glass and mineral fiber. The investigation itself had two major phases. During the first phase potential methods to determine in-situ conductivity were identified and examined. The second phase dealt with acquiring field data on insulation performance and the analysis thereof.

During the first phase of the study, methods to determine accurately heat flow, pipe temperature and surface temperature were identified. These methods were validated against measurements taken on a pipe test apparatus described in Appendix A. For determining heat flow from a pipe a "heat flow" meter was used. This meter consists of a material of known thermal conductivity with thermopiles buried in it. By accurately measuring the temperature difference across the material and knowing the conductivity of the material, the heat flow can be determined. Heat flow meters from various manufacturers were examined in order to find one compatible with the requirements of the study. Once a suitable meter was selected on the basis of stability and accuracy, a calibration was performed to determine whether various jackets, air velocities, insulations, etc. would have an effect upon its operation. The only factor which did have an effect was the manner in which the meter was held to the surface being tested. After some experimentation a way was found which yielded consistent results within an acceptable accuracy. Unfortunately, the same was not true for the temperature measurements.

It was not possibie to obtain the desired accuracy and, as such, some differences between measured and actual temperatures existec. 
Once the objectives of Phase I of the study were achieved, field data gathering activities were initiated. A total of 94 acceptable data sets were collected. The heat flows and temperatures measured were used to calculate the thermal conductivity of the insulation. This calculated value was compared to those used in the "Economic Thickness for Industrial Insulation" manual prepared for the Federal Energy Administration by York Research $(1)^{*}$. These values were supplied by insulation trade associations and can be taken to represent an "average" of conductivity values from different manufacturers. . In comparing the two values a " $t$ " test was used to test for significance. The results of this test indicated that differences in the data sets were significant and were positive, that is, measured values were usually larger than design values. Having determined that significant differences did occur, an analysis of variance and a stepwise correlation analysis was performed. However, it was not possible to pinpoint the cause of the difference.

* Numbers in parenthesis refer to references which can be located in section 7.0 References. 


\subsection{RECOMMENDATIONS}

It has often been noted that the major recommendation of most research projects is a call for more research in the area being investigated and/or increased funding to further such investigation: Unfortunately, the same holds true for this project with, however, a slight difference in emphasis. The project was an investigation to determine whether a discrepancy existed between actual versus expected industrial insulation performance. Furthermore, if such a discrepancy was found it was hoped that the investigation would be able to identify the cause of the difference. As it turns out, a discrepancy was found but the reason behind it was not. As can be expected, therefore, the recommendations are directed toward an explanation of why discrepancies in conductivities were found. . It is believed however, that funding. for the majority of any future work should come from the private rather than the Federal sector. The government has fulfilled its obligation to the public by discovering that such a phenomena is occurring. It should now be the responsibility of industry to validate or contradict the conclusions of this report and to research, if necessary, the causative agent of the phenomena's occurrence and proceed with any other research work whose necessity may later become apparent.

In view of the remarks, the recormendations offered as a result of this study are as follows:

1. A comprehensive effort should be made to validate the results of this study. This effort should be divided into two prime study areas. The first area wolild involve the in-situ instrumentation. Precision and accuracy of the overall measurement scheme should be better defined than was possible during this study. Temperature measurement probes in particular should be investigated to determine whether a better design is possible. The second area would be to perform another field survey. It would be hoped that more data points could be gathered and more 
diverse factors be investigated as potential causes of insulation performance degradation.

2. Should another such study confirm the results of this report, then the economic consequences of the difference between actual and advertised thermal conductivities should be evaluated.

It should be noted that it could be in the national interest to further research into preventive measures to retard insulation degradation (if such does indeed occur) or to come up with a new type of insulation which would be immune to such an effect. Such a program, however, may not be in the best interest of the insulation manufacturers.

In summary, the work described in this report should be continued for the purpose of validation. Funding for a validation study should come from the industry. If the validation is positive, an analysis should be performed by the government, to ascertain national economic impact. If the impacts prove substantial, then it would be incumbent upon the industry to fund research aimed at correcting the problem. 


\subsection{INTRODUCTION}

\subsection{General}

While insulation can be applied for many purposes (worker safety, process economics, etc.), it has but one prime function - to retard the flow of heat. An inverse measure of this function is the thermal conductivity of the insulation. Conductivity is a measure of how well heat is conducted.through a material. Such a measure is usually the prime consideration by purchasers of industrial insulation. This is not to discount the importance of other factors such as capital" and installation cost. It is typical today for an industrial insulation buyer to have a complex economic analysis, such as life cycle costing, performed in order that the "proper" amount of insulation is applied. With this level of sophistication it becomes apparent that certain assumptions concerning insulation needed re-examination. As a result of these concerns, an assessment on industrial thermal insulation was performed by the Oak Ridge National Laboratory for the Energy Research and Development Administration. (2) This assessment highlighted, among other things, the need for realistic in-service performance data. In the Recommended Actions section of the report the first action Iisted was

" To initiate a cooperative Federal - private industry program to obtain realistic in-service performance data on insulation systems. Potential application areas are to include the full temperature range from cryogenic to high temperatures. The results would provide a data base for efficient design and cost-benefit analyses."

As a result of this recommendation a program was initiated to examine the performance of industrial insulation as determined from field measurements. This report presents the results of that program. 


\subsection{Objectives}

At the time this study was conceptualized there was uncertainty as to precisely the prime objective of the program. The school of thought was essentially divided into two categories:

1. Should actual performance of high-temperature insulation be compared to what was expected, i.e., actual vs. measured thermal conductance, or,

2. Should the basic thermal property of high-temperature insulation be checked to determine if degradation has occurred,"1.e., has the themal enductivity changed?

The first objective would tend to provide an overall picture of insulation performance. The conductivities, density, condition, etc. would all be noted. The prime disadvantage of this approach is that a much larger population must be sampled than would be necessary for the second approach. Another disadvantage would be that such a scheme requires an extremely complex analysis such that the effects of various factors could be sorted out, one from the other.

The second ubjective for the program, while being less ambitious, appeared to present the greater chance of being brought successfully to a conclusion. To determine whether insulation retained its original shape and density or if other physical properties where somehow modified by use was left, therefore, to future researchers. This study then would be restricted to that insulation which was not severely handled or subject to deformation.

Since the prime objective of the program was also limited to evaluation of the thermal conductivities of high temperature insulations in use, it was necessary to define more precisely whether any one causative factor should be the prime focus of the study. Various factors (other than those physical factors previousiy discussed) were considered, however it was decided that the most interesting factor and the one whose 
effect had never before been quantified was insulation age.

Once the prime objective and focus of the program was defined, it became evident that to accomplish the stated objectives a number of preliminary goals had to be achieved. First, since age would be the focus of the program, a field-oriented study was in order. The question then arose as to whether or not in-situ measurements were necessary or if specimens from the field could be returned to the laboratory for analysis. The former alternative appeared to be the most viable (refer to Section 4.1 APPROACH for further explanation). This decision necessitated that another objective of the program be the development of techniques for the accurate measurement of in-situ thermal conductivities.

In summary, then, the program had three major objectives:

1. To develop a methodology which would enable the in-situ measurement of thermal conductivities of high temperature insulations .

2. To determine whether a discrepancy existed between those thermal conductivity values expected from the manufacturers' iiterature and those determined by in-situ measurement."

3. To determine whether insulation age was the causative factor should any difference in thermal conductivities be found; also, to attempt to identify other factors which may be responsible for an affect on performance. 


\subsection{APPROACH AND METHODOLOGY}

\subsection{Approach}

As noted previously, it was ascertained that a field study was in order since artificial aging of new insulations in the laboratory was non-viable and sure to generate controversy. The first problem to be addressed then was how to sample in the field and what sort of samples should be collected. The second problem was how to measure accurately the conductivity of the sample without biasing the results. The solution to these problems was to go to a plant, remove a sample of the insulation and then subject it to some kind of standardized test procedure. Since the removal of a large sample of insulation might be of concern to plant management, it would be necessary to minimize sample size. Also, and more inportantly, the act of removing and then transporting a sample was sure to affect' the insulation's properties in some manner. In order to provide an accurate accounting of the magnitude of such an effect, an experimental program would have to be conducted. Such a program would have lnvolved insulation in use for some time. An experiment conducted with only new insulation might not produce valid results. Insulation in use for some time having been subjected to temperature variations, moisture, etc., may exhibit a markedly different reaction to handing than new insulation. A dilemna then exists in that a "control" group of aged insulation is not available. The experiment could not be done and, therefore, the effects of sampling and handling on the insulation's thermal conductivity cannot be quantified. Since it appeared reasonable that this handing effect might be substantial and could not be quantified, the only available option then would be to somehow measure all of the parameters of concern in the field. Accordingly, the approach to quantify the parameters necessary to achieve the stated prime objective (i.e., objective No. 2 in Section 3.2) would be utilization of in-situ type measurements. 
The question of what specific data should be collected to identify factors (if any) responsible for significant differences in insulation conductivities should be addressed. Those factors considered to have a high degree of potential in contributing to the degradation of insulation thermal conductivities include :

- temperature variability in the process stream being insulated, i.e., cyclic nature of the stream.

- pipe location, i.e. inside or out of doors.

- general environment of the surroundings with respect to potential corrosive conditions.

- overall condition of the insulation.

- age of the insulation

Other factors in the field data acquisition phase of the program which could have some effect on the accuracy of the readings were ambient temperature and air velocity over the pipe. For purposes of categorization, the type of insulation and jacket were noted. Moisture in the insulation was also measured.

In order to calculate the thermal conductivity of the insulation, the following must also be measured: pipe temperature, insulation surface temperature, insulation thickness and circumference and heat flow through the insulation. Thermal conductivity for pipe insulation is determined by the formula:

$$
k=\frac{Q\left(r_{2} \ln \left(r_{2} / r_{2}\right)\right.}{t_{1}-t_{2}}
$$

where

$$
\begin{aligned}
k= & \text { thermal conductivity, BTU-in/ft }{ }^{2} \mathrm{hr}{ }_{F} \\
Q= & \text { heat flow, BTU/ft hr } \\
r_{2}= & \text { outer radius of insulation, in. } \\
r_{1}= & \text { inner radius of insulation, in } \\
t_{1}= & \text { temperature of inside surface of } \\
& \text { insulation, of } \\
t_{2}= & \text { temperature of outside surface of insulation, } o_{F}
\end{aligned}
$$


To analyze this field data it was obvious that the first statistical analysis to be performed would have to determine whether or not a significant difference did indeed exist between the measured and the expected conductivities. For this type of analysis a " $t$ " test was expected to prove sufficient. If a significant difference was found, then an analysis of variance and a multiple regression analysis would be performed to attempt to correlate one of the aforementioned factors with the difference.

\subsection{Methodologies}

The followiny sectione dotail the various methods, instrumentad and otherwise, which were used to generate the data in this study. In most cases complete descriptions of these methods are given along with any difficulties encountered.

\subsubsection{Expected thermal conductivity values}

The entire research program was a comparison between two sets of numbers; nartely, the expected thermal conductivities of various high temperature industrial insulations and those which were measured. It is obvinis that equal importance should be attached to the manner in which each set' of numbcrs is genprated. Accordingly, every effort was made to generate aocurate data on expected conductivity values. There were, however, a number of problems in accomplishing this. First, when a field measurement was made the vast majority of the insulations could not be identified with respect to manufacturer. As such, it became necessary to use as the expected values an average of various manufacturers' values. Second, conductivity values of the various manufacturers were not readily available for a period extending back over the last twenty yedrs. Finally, even i,f such values were available, there would exist the problem of data reliability since both test methods and quality control procedures for the insulation industry were not well developed or implemented until recently. The conclusion reached from these facts is that an. "accurate" baseline data set for insulaticconductivity values is not available. The question then becomes, 
what type of data is available and what is its accuracy. Various equations have been generated to describe conductivity performance with temperature. For purposes of this study, it was felt that the equations generated by the industry would be the most acceptable. Therefore, the equations generated by the Thermal Insulation Manufacturers Association for use in the "Economic Thickness for Industrial Insulation" manual (1) were selected. These equations are as follows:

for mineral wool

$$
k=7.0 \times 10^{-4} \cdot t_{m}+0.18
$$

for fiber glass

$$
k=7.685 \times 10^{-3}\left(t_{m}+460\right) 0.5+3.016 \times 10^{-10}\left(t_{m}+4603(E q \cdot 3)\right.
$$

for calcium silicate

$$
k=0.3754+6.857 \times 10^{-5} t_{m}+5.7143 \times 10^{-7} t_{m^{2}}
$$

where

$\mathrm{k}=$ thermal conductivity, BTU-in/hr $\mathrm{ft}^{2} \mathrm{o}_{F}$

$t_{m}=\frac{t_{p}+t_{a}}{2}$

$t_{p}=$ process temperature, $O_{F}$
$t_{a}=$ ambient temperature, ${ }_{F}$

The above equations are the best presently available. If the numbers generated by these equations do not accurately. reflect the true "expected" conductivity values of the insulations tested then the conclusions from this study could be affected.

\subsubsection{Heat flow}

The measurement of heat flowing outwards from the insulation is the single most important type of measurement made during the entire program. This is not because of the sensitivity of the thermal conductivity calculation to inaccuracies in the technique (since other parameters have a greater effect) but, rather, due to the lack of general usage and trust associated with such measurements. Once it was clear, however, that an in-situ device was necessary for completion of the program, then the only. question remaining was which technique was best. After due 
consideration of several techniques, the only instrument which possessed the characteristics of portability and accuracy was a "heat flow" meter. The meter operates as follows: (3)

" Heat flow meters operate on the principle that a heat flow passing a thin disc generates a temperature difference across the disc. A heat flow meter is designed in such a way that the temperature difference remains very small, thus minimizing the influence of the meter on the heat flow to be measured. A large number of thermocouplos, fitted in the disc in such a way that the "junctions" are in contact with the surfaces, measure the temperature difference across the disc. The voltage generated in the thermocouples is proportional to the heat flux passing the disc. The proportionality factor (calibration constant) is determined by calibration of each meter. The unknown heat flow is found by multiplication of the voltage value by the oalibration constant."

Of course, there were a number of factors which had to be checked out prior to using this type of device. First and foremost was the instrument's overall accuracy. Second, the effect of factors such as the emissivity differences of different types of insulations had to be quantified. Third, the calibration procedure had to be developed. These and other problems had to be resolved before the meter could be used with confidence. To answer these questions a system had to be constructed which could be used to calibrate the meter and which could be used to account for various interfering factors (such : as different jackets). It was decided to carry out a limited experimental program using a thermal conductivity pipe insulation instrument. This instrument is described in detail in." Appendix A which is a report by the instrument's manufacturer, Sparrell Engineering Research Corporation. The overall accuracy of the instrument is given in this report as $3 \%$. 
various types and sizes of heat flow meters were evaluated during the preliminary calibrations. It was determined that the WS-32 model of the Institute of Applied physics, located in Delft, Netherlands, due to its high signal output per unit of heat flow and its stability, was the most acceptable of the available units. With this determined, it was then necessary to examine the manner in which. the instrument would be attached to the insulation. Various techniques were attempted but the one which appeared to give the best results was to tightly attach four meters ninety degrees apart onto the insulation by means of an elastic type cloth (e.g., an ace bandage). Some difficulty was encountered when measuring heat flow from insulations surrounded by metallic jackets. It was necessary for those cases to insulate the meters from the metal to achieve good results. However, there appeared to be no difficulties with other jacket or insulation types or from an increase in air velocities over and around the test pipe.

Results from the calibration tests for the meter can be found in section 5.0, RESULTS. It suffices here to state that the instrument performed in a manner which would enable the gathering of the required data within the accuracy limits imposed.

\subsubsection{Temperature measurement}

Two temperature measurements were necessary for the conductivity calculation; namely, the temperature at the surface of the insulation and the temperature of the pipe. Each measurement presented unique difficulties to be evaluated and compensated for prior to field use. The first problem was a general one. Should the two temperature readings be taken simultaneously and at the exact same location with the heat flow measurement? Obviously, such a procedure would present the ideal case; however, physical constraints made such a procedure impossible. To measure the surface temperature of the pipe the primary constraint was the necessity to cut into the insulation and, by doing so, in all probability change the heat flow pattern in the vicinity of the cut. Such a change would affect the surface temperature and heat flow measurement. It was necessary, 
therefore, for the readings to be either simultaneous or in the exact same location. However, both test conditions could not occur. It was decided, therefore, that the measurements would be taken at the same time with one measurement location slightly apart from the other.

The determination of pipe temperature presented the more formidable measurement problem. After various attempts to use commercial devices it was found that either the accuracy or the durability needed from such instruments was not achievable. A device was, therefore, constructed to meet the criteria of accuracy and durabil1ty. The probe cunsisted of a porcelain rod approximately ten inches in length with a copper cap. An iron-constantan thermocouple was silver soldered onto this cap. A special compound having a high thermal conductivity rating was placed on the tip of the probe to aid in the contact. The device was held in place by straps. Finally; a hand rasp was used on the pipe to remove surface irregularities and to further assure good contact. Calibration of the probe was performed by checking the measured values against the average temperature indicated by thermocouples attached to the pipe of the insulation test apparatus (previously referred to and described in Appendix A). The results of this calibration can be found in section 5.2 .3 .

In a similar manner the surface temperature of the insulation was determined. Four thermocouples (iron-constantan) were attached to the insulation ninety degrees apart. - Calibration was performed on the pipe test apparatus as before.

\subsubsection{Other measurements}

Other measurements made in the course of this study were performed in the field. These measurements included the circumference of the pipe and insulation, the insulation thickness, the amount of moisture in the insulation and the velocity of the air around the system. The only measurement of any concern was the moisture. As mentioned previously, since the objective of this study was to measure changes in thermal conductivity and not performance, measurements were made only when it was 
obvious that the insulation was not subjected to any overt external forces and when the insulation retained its original shape. Moisture, however, would have to be accounted for in some manner. It was decided that because only elevated temperature systems were being investigated, the moisture test could be somewhat lacking in sensitivity., if they were performed in the field. A test system utilizing calcium carbide as a water reactive reagent.was, therefore, used.

\subsection{Overview of Field Measurement Procedures}

In order to insure that the same general test conditions were observed at each site, the following criteria were used in selecting the sample location:

- the location was to be on a horizontal length of pipe not less than five feet iong with no puncture or external attachment present.

- there could be no evidence of external damage.

- the original shape of the insulation must be evident.

All measurements were taken simultaneously and recorded on a data sheet (see Figure 1 ). The type of environment in which the insulation was situated and the overall condition of the insulation was, of course, judgemental in nature and subject to interpretation. To minimize variation the same person made these observations at each site. 


\section{Figure 1}

\section{FIELD DATA SHEET}

1. Type of insulation mineral fiber

2. Type of jacket ASJ w/alum.

3. Temperature variability

4. Indoor (1) or Cutdoor (2)

5. Environment

6. Overall condition

7. Age of insulation installation (years)

8. Nominal pipe size (in.)

9. Ambient temperature $\left({ }^{\circ}\right)$

10. Air velocity over pipe (Ft/min)

11. Insulation circumference

12. Measured insulation thickness

13. Heat flow (mv)
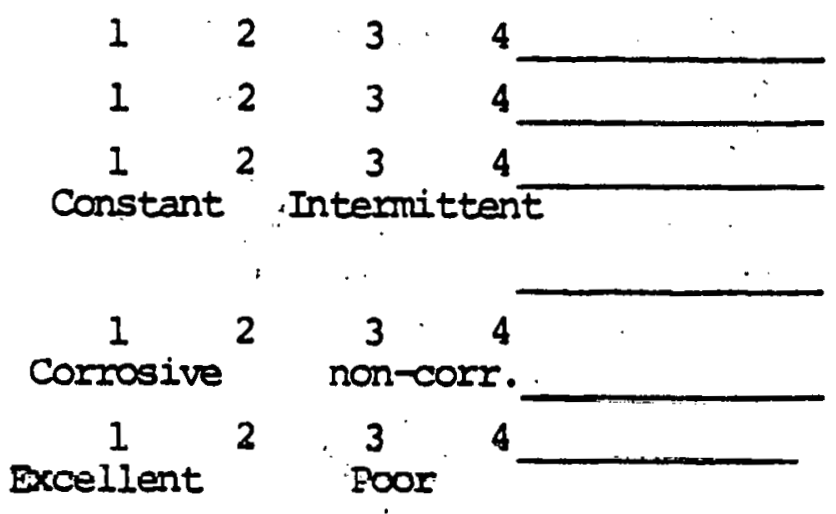

(a)

14. Pipe surface temperature (mv)

top
bottom
side

14. Pipe surface temperature (mv)

$\# 1$

15. Insulation surface temperature (mv)

\#2

\#3

\#4

$\# 1$

\#2

$\# 1$

$\$ 2$

$\# 3$

$\# 4$

16. Moisture content ( 8 d.w.) 


\subsection{RESULTS}

\subsection{General}

The results obtained from this program are divided into two categories. The first has to do with the calibrations and other analyses performed on the instruments utilized. The second category contains the data obtained during the field investigation part of the program and the associated analyses.

\subsection{Calibration Results}

5.2.1 Pipe insulation instrument - While it cannot be considered a "calibration" per se, the apparatus used to calibrate the heat flow meters and temperature probes was subject to review. In Appendix A, as was noted previously, the instrument designer in his error analyses derives an accuracy of three percent. To supplement this analysis, Oak Ridge National Laboratory performed a computer analysis of the tester. Their report can be found in Appendix B. The conclusions of the analysis are that "...the Pipe Tester system shows the calculated specimens thermal conductivity agrees with the input specimen thermal conductivity to 0.38 for a $30^{\circ} \mathrm{F}$ temperature difference between the stainless steel mid-point and web section. A 38 difference was noted for a $150^{\circ} \mathrm{F}$ temperature difference. This is a very favorable result and suggests a useful operational control prescription." As such, the pipe tester's performance was deemed satisfactory for the purposes of the study.

5.2.2 Heat flow meters - As previously noted the heat flow meters were considered to be the critical element of the testing program. Their use has been relatively restricted in this country and consequently results would be subject to close scrutiny. The results of the calibrations $c$ an be found in Table $I$. Since it 
TABLE 1

HEAT FLOW METER CALIBRATION DATA

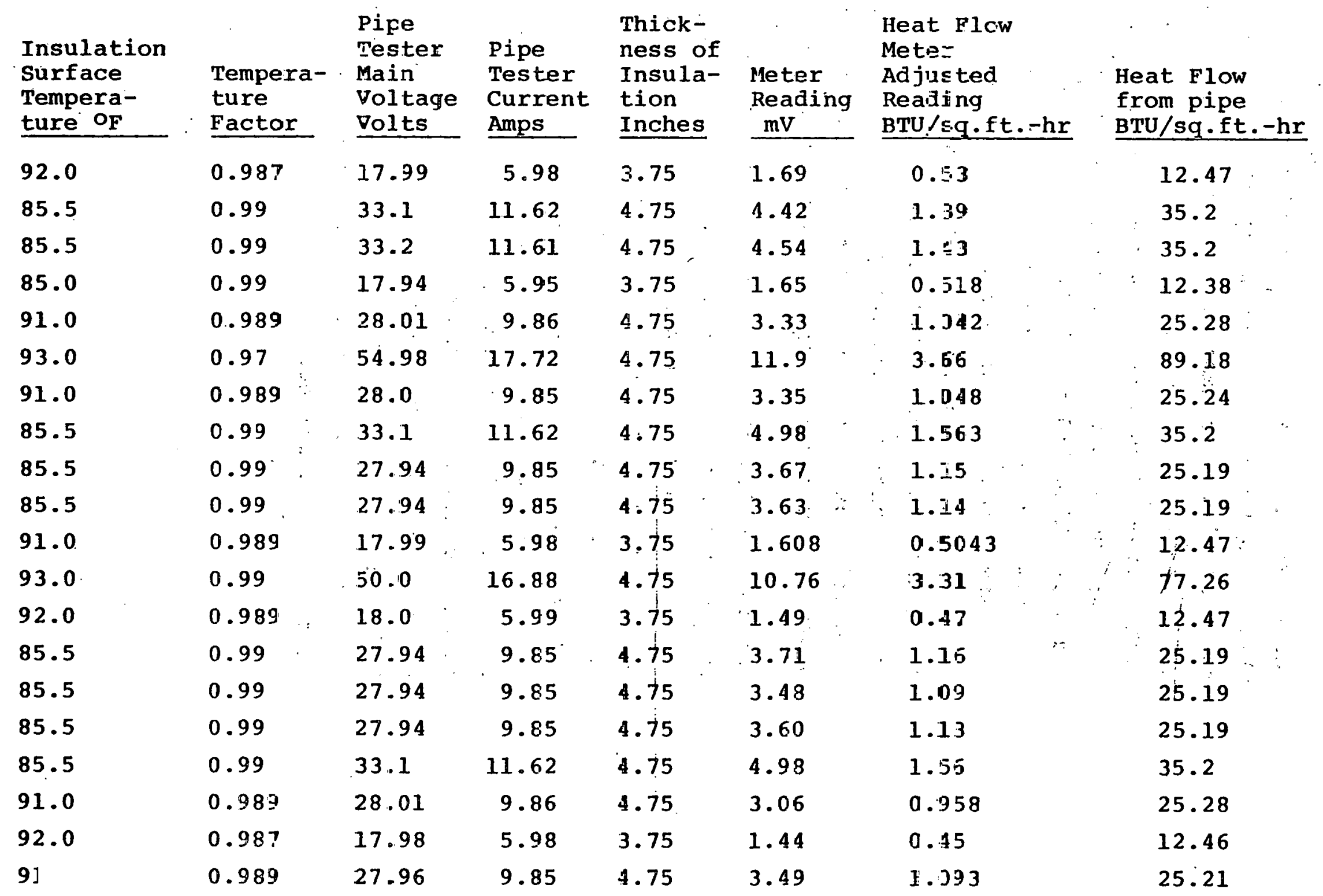


was known that the surface temperature of the meters slightly affected the results this was factored into the analysis. The last two columns show the adjusted heat flow reading and the actual heat flow (as measured by the power dissipated from the insulation pipe tester). These numbers were then subject to a curve-fit type analysis which indicated that a linear equation would best fit the data. A scattergram of the data along with the line formed by the linear equation can be found in Figure 2.: The 958 confidencel limits around the predicted values are given in Table 2 . From this data it can be inferred that for the highest heat flow recorded, the difference between the actual and the measured (by meter) value would be about five percent.

The above calibration analysis was performed using various types of jackets and insulations. As noted previously, during the preliminary testing it was discovered that the metallic jackets interfered with the heat flow sensors. Subsequently, the sensors were shielded from direct contact with the jackets and, as the calibration results confirm further effects were negligible. The effect of air velocity on the measurement was also investigated during the calibration study. Readings were made with the air velocity in the vicinity of the heat fiow meters at 0 and then at 10 , 20 , and 30 feet per second. No difference in the readings was discerned. 
FIGURE 2

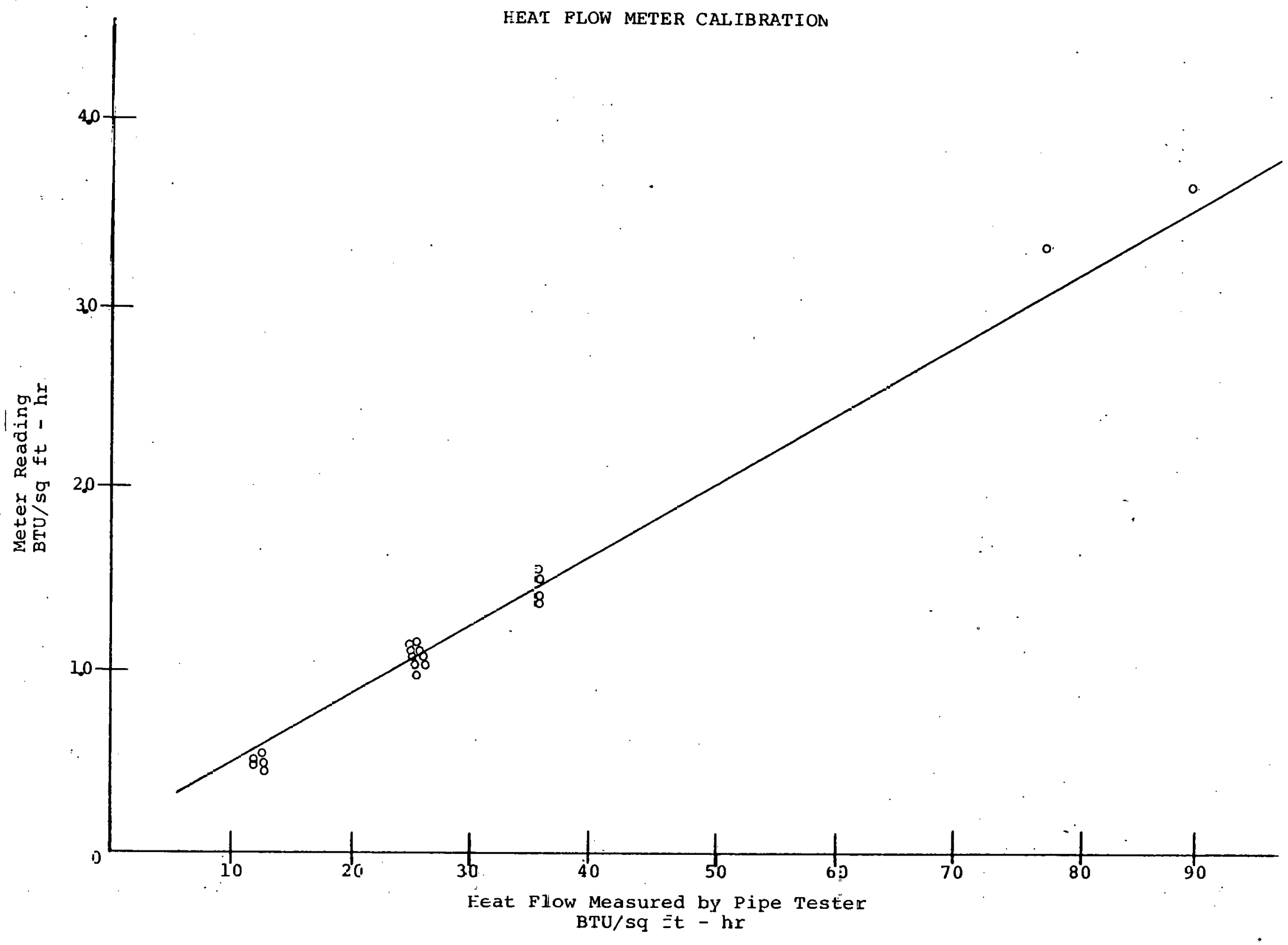


TABLE 2

CONFIDENCE LIMITS DATA

\begin{tabular}{|c|c|c|c|c|}
\hline $\begin{array}{l}\text { Heat Flow } \\
\text { Measured } \\
\end{array}$ & $\begin{array}{l}\text { Heat Flow } \\
\text { Observed } \\
\end{array}$ & $\begin{array}{l}\text { Heat Flow } \\
\text { Estimated }\end{array}$ & $\begin{array}{l}\text { Non-sin } \\
95.008 \\
\end{array}$ & $\begin{array}{l}\text { nultaneous } \\
\text { Confidence Iimits }\end{array}$ \\
\hline 1.5630 & 35.200 & 37.231 & 36.386 & 38.075 \\
\hline 1.3900 & 35.200 & 33.119 & 32.318 & 33.919 \\
\hline 1.4300 & 35.200 & 34.070 & 33.262 & 34.877 \\
\hline 1.3900 & 35.200 & 33.119 & 32.318 & 33.919 \\
\hline 0.51800 & 12.380 & 12.393 & 11.333 & 13.453 \\
\hline 1.0420 & 25.280 & 24.847 & 24.033 & 25.662 \\
\hline 1.0480 & 25.240 & 24.990 & 24.177 & 25.803 \\
\hline 0.95800 & 25.280 & 22.851 & 22.013 & 23.689 \\
\hline 0.50430 & 12.470 & 12.067 & 10.998 & 13.137 \\
\hline 0.53000 & 12.470 & 12.678 & 11.625 & 13.731 \\
\hline 0.4 .7000 & $12.470^{\circ}$ & 11.252 & 10.160 & 12.344 \\
\hline 0.45000 & 12.460 & 10.777 & 9.6714 & 11.882 \\
\hline 1.1400 & 25.190 & 27.177 & 26.380 & 27.973 \\
\hline 1.1500 & 25.190 & 27.414 & 26.619 & 28.210 \\
\hline 1.1600 & 25.190 & 27.652 & 26.858 & 28.446 \\
\hline 1.0900 & 25.190 & 25.988 & 25.184 & 26.793 \\
\hline 1.1300 & 25.190 & 26.939 & 26.141 & 27.737 \\
\hline 1.0930 & 25.210 & 26.060 & 25.256 & 26.863 \\
\hline 3.6600 & 89.180 & 87.072 & 84.615 & 89.529 \\
\hline 3.3100 & 77.260 & 78.754 & 76.614 & 80.893 \\
\hline
\end{tabular}




\section{2 .3 Temperature measurements}

The surface and pipe temperature measurement calibration data can be found in Table 3. A linear regression analysis was performed on each set of data. For the surface temperature the correlation index was high (f $>0.8$ ) and this indicated that the measurements were good. For the second set of data on the pipe measurements the correlation was somewhat lower due, undoubtedly, to difficulties in achieving a good contact between probe and sensor and due lo those calibration problems unique to this system as described in section 4.2.3. The accuracy of both systems, however, appears acceptable from the confidence limits data in Table 4. . 
TABLE 3

TEMPERATURE MEASUREMENT CALIBRATION DATA

Position

Pipe

Pipe

Pipe

Pipe

Pipe

Pipe

Pipe

Pipe

pipe

Pipe

surface

Surface

Surface

Surface

Surface

Surface

Surface

Surface

Surface

Surface

Surface

Surface

surface

Surface

surface

Surface

Surface

Surface

surface

Surface

Surface

Surface

Surface
Measured Value ${ }^{\circ} F$

327.0

326.0

326.0

325.0

332.7

330.4

340.5

328.2

316.7

309.3

96.8

97.5

94.4

94.4

91.0

90.2

95.0

95.5

90.9

90.0

95.8

95.8

90.9

90.3

96.0

95.8

90.3

96.3

95.8

94.4

108.2

108.2

109.5
Pipe Tester Value ${ }^{O_{F}}$

332.0

332.0

332.0

332.0

344.8

344.7

344.7

343.8

321.0

329.4

95.3

88.5

93.9

.94 .2

91.3

87.9

92.0

94.1

92.3

88.9

93.9

95.9

94.8

93.0

88.9

9.5 .9

89.9

95.5

95.5

93.1

110.3

110.5

113:7 
TABLE 4

CONFIDENCE LIMITS DATA

a. Pipe Temperature

Temperature

Pipe

Tester

332.00

332.00

332.00

332.00

344.80

344.70

344.70

343.80

321.00

329.40
Temperature

Observed

327.00

326.00

326.00

325.00

332.70

330.40

340.50

328.20

316.70

309.30

b. Surface Temperature

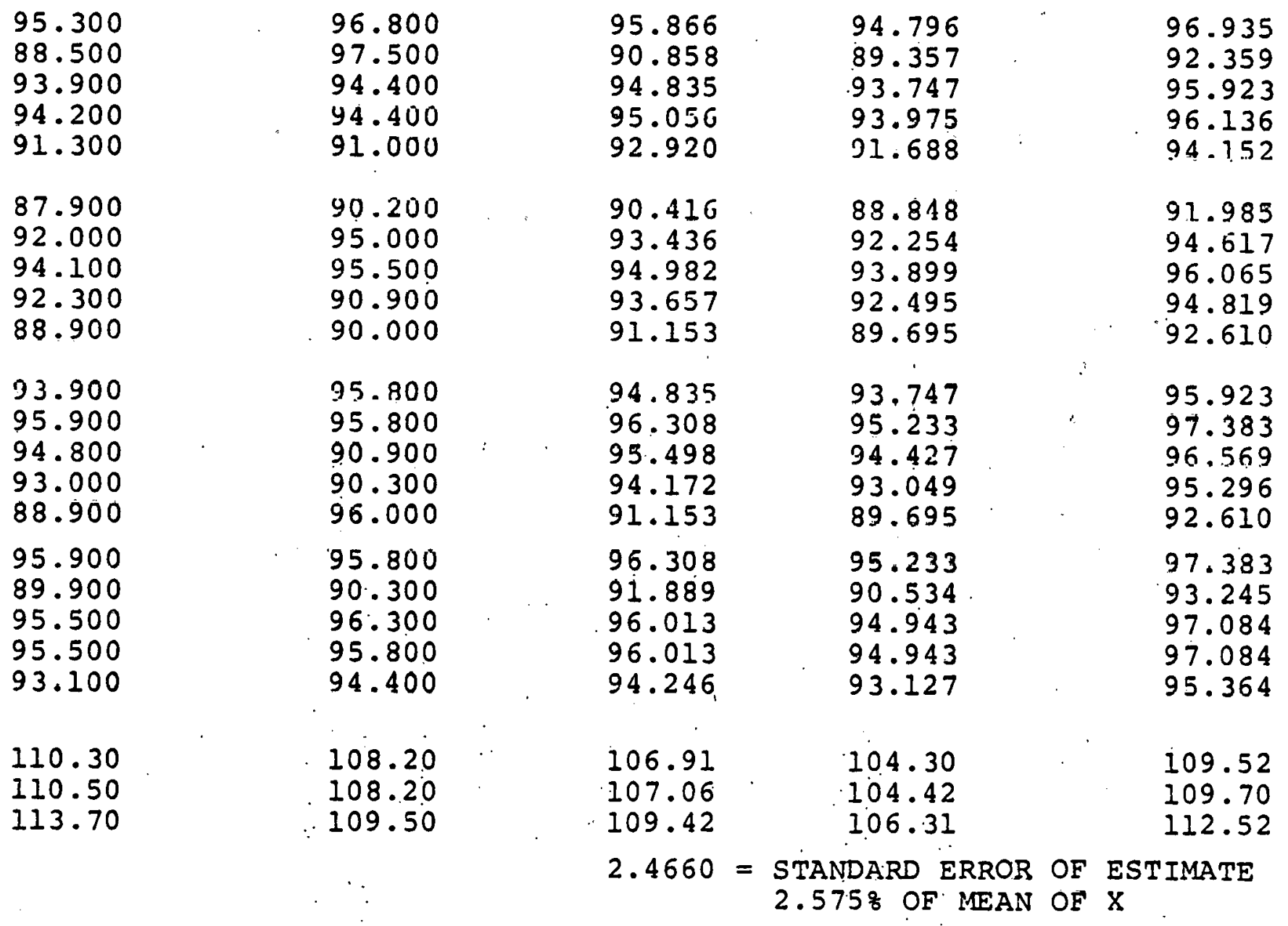

Temperature Non-Simultaneous

Estimated

323.30

323.30

323.30

.323 .30

333.42

333.34

333.34

332.63

314.61

321.25

$5.6818=$ STANDARD ERROR OF ESTIMATE $1.742 \%$ OF MEAN OF X1
327.87

327.87

327.87

327.87

339.78

339.66

339.68

338.60

323.35

326.53 
2.3 Field Results

The field data and results of this study are summarized in Tables 5, 6, and 7. In all, ninsty-one sets of data were obtained.. Twenty-one sets were for mineral fiber, twentysix for glass fiber and forty-four for calcium silicate insulation.

\subsection{Statistical Analysis}

5.4.1 Test for significant difference - A " $t$ " test was used to determine if a significant difference existed between the thermal conductivities measured and those which were expected from the performance equations. For the set of all values, as well as for the sub-sets for each insulation, it was determined that the conductivity measured was significantly larger than the expected values.

5.4.2 Analysis of variance - In order to best understand what the cause of the significant difference might be, an analysis of variance was performed on the entire data set. Since this type of analysis is used only for. categorical variables, it was limited to insulation type, jacket type, temperature variability, environment and overall condition. In examining the effect that the type of insulation might have had on the results, the difference between the measured and expected values was used. The results of this analyses can be found in Tabie $8 a$. The F ratio noted is significant at the 0.05 levei: To investigate this significant result still further, the average differences for each of the three insulations can be compared using. Tukey's studentized range. As a result it was found that the calcium silicate and mineral fiber insulations give much the same value for the difference between measured and expected conductivity value than the other two for this difference. 
IAnI.F. 5

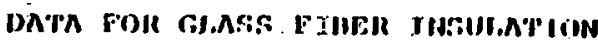

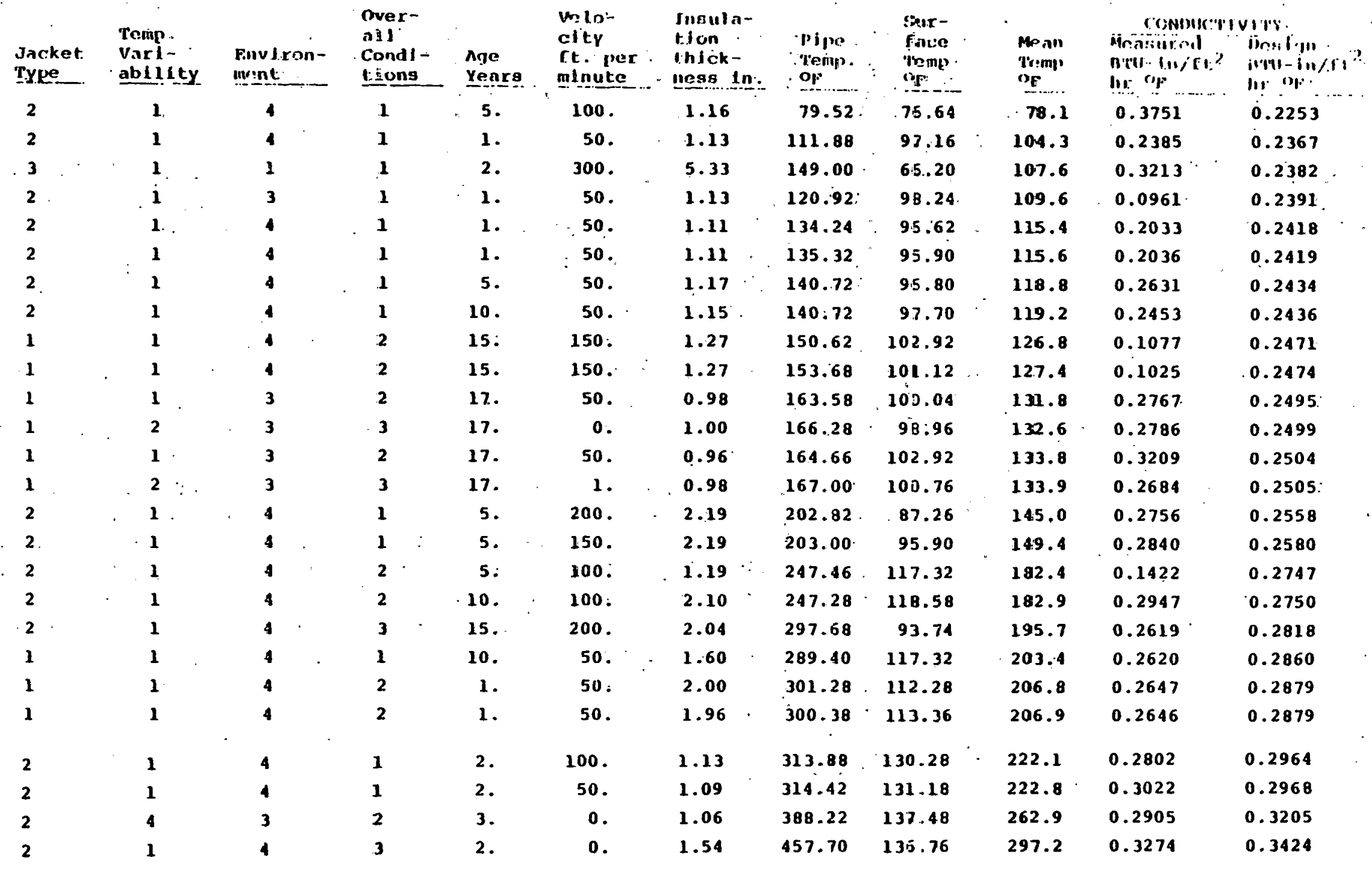


TABLE 6

DATA FOR MINERAL FIBER INSULATION

\begin{tabular}{|c|c|c|c|c|c|c|c|c|c|c|c|}
\hline $\begin{array}{l}\therefore \\
\text { Jacket } \\
\text { Iype } \\
\end{array}$ & $\begin{array}{l}\text { Temp. } \\
\text { Var1- } \\
\text { ab11Ity }\end{array}$ & $\begin{array}{l}\text { Environ- } \\
\text { ment }\end{array}$ & $\begin{array}{l}\text { Over- } \\
\text { a } 11 \\
\text { Cond1- } \\
\text { tlons }\end{array}$ & $\begin{array}{l}\text { Age } \\
\text { Years }\end{array}$ & $\begin{array}{l}\text { Velo- } \\
\text { city } \\
\text { ft. per } \\
\text { minute }\end{array}$ & $\begin{array}{l}\text { Insula- } \\
\text { ticil } \\
\text { thick.. } \\
\text { ness ln. }\end{array}$ & $\begin{array}{l}\text { Plro } \\
\text { Temp. } \\
\text { OF. }\end{array}$ & $\begin{array}{l}\text { Sur- } \\
\text { face } \\
\text { Tenup } \\
\text { OF }^{-}\end{array}$ & $\begin{array}{l}\text { Man } \\
\text { Temp. } \\
\text { of. }\end{array}$ & 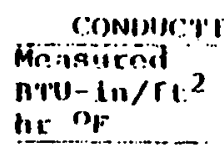 & 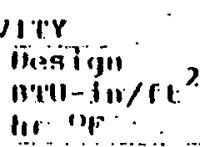 \\
\hline 3 & 1 & 3 & 2 & 2. & 50 & 2.87 & 154.40 & 76.82 & 115.6 & 0.3307 & 0.2609 \\
\hline 3 & 1 & 3 & 2 & 2. & 170. & 2.16 & 154.40 & 77.54 & 116.0 & 0.2688 & 0.2612 \\
\hline 3 & $\therefore 1$ & 3 & 2 & 2. & 100 & 2.08 & 152.24 & 79.70 & 116.0 & 0.2419 & 0.2612 \\
\hline 2 & $\therefore 1$ & 3 & 1 & 2. & 50 & 2.75 & 149.00 & 83.30 & 116.1 & 0.3382 & 0.2613 \\
\hline 3 & $\therefore \mathbf{1}$ & 3 & 3 & 2. & 50. & 2.66 & 157.10 & 77.54 & 117.3 & 0.2766 & 0.2621 \\
\hline 2 & 1 & 3 & 1 & 2. & 100 & 2.96 & 149.72 & 88.34 & 119.0 & 0.4150 & 0.2633 \\
\hline 2 & 1 & 3 & 1 & 2. & 100 & 1.61 & 215.42 & 96.08 & 155.7 & 0.3702 & 0.2890 \\
\hline 2 & 1 & 3 & 1 & 2. & 80 & 1.67 & 215.42 & 96.80 & 156.1 & 0.3285 & 0.2893 \\
\hline 3 & 2 & 3 & 2 & 15 . & 100 & 2.14 & 367.88 & 66.20 & 217.0 & 0.4382 & 0.3319 \\
\hline 3 & 3 & 3 & 2 & 15. & 70 & 2.14 & 394.52 & 105.08 & 249.8 & $0.3477^{\circ}$ & 0.3549 \\
\hline 3 & 2 & 3 & 2 & 15. & 75 & 2.14 & 411.98 & 109.04 & 260.5 & 0.3615 & 0.3624 \\
\hline 1 & 1 & 3 & 2 & 17. & 100. & 1.00 & 432.50 & 158.90 & $295: 7$ & 0.4732 & 0.3870 \\
\hline 1 & 1 & 3 & 2 & 17. & 120 & 1.00 & 487.40 & 147.02 & 317.2 & 0.2951 & 0.4020 \\
\hline 1 & 1. & 3 & 3 & 17. & 180 & 0.98 & 482.72 & 156.92 & 319.8 & 0.4147 & 0.4039 \\
\hline 1 & 1 & 3 & 2 & 17. & 120 & 1.00 & 499.82 & 141.62 & 320.7 & 0.2888 & 0.4045 \\
\hline 1 & 1 & 3 & 2 & 17 & 130 & 1.00 & 498.20 & 147.56 & 322.9 & 0.3006 & 0.4060 \\
\hline 1 & 1. & 3 & 2 & 17. & 120 & 1.00 & 498.20 & 153.32 & 325.8 & 0.3196 & 0.4080 \\
\hline 3 & 1 & 3 & 2 & 2. & 200 & 3.81 & 658.04 & 95.72 & 376.9 & 0.4301 & 0.4438 \\
\hline 3 & 1 & 3 & 2 & 2 . & 250 & 3.81 & 658.04 & $95.72:$ & 376.9 & 0.4191 & 0.4438 \\
\hline 3 & 4 & 3 & 3 & 2. & 50 & 4.63 & 849.38 & 141.44 & 495.4 & 0.6534 & 0.5268 \\
\hline 3 & 4 & 3 & 3 & 2. & 75. & 4.92 & 870.62 & 152.96 & $511: 8$ & 0.8497 & 0.5383 \\
\hline
\end{tabular}


TABLE T

DAI' FOH CALCIUH SILICATE IRSULATION

\begin{tabular}{|c|c|c|c|c|c|c|c|c|c|c|c|}
\hline $\begin{array}{l}\text { Jacket } \\
\text { Type } \\
\end{array}$ & $\begin{array}{l}\text { Temp:: } \\
\text { Var1-: } \\
\text { ab111Ly }\end{array}$ & $\begin{array}{l}\text { Finviron- } \\
\text { ment }\end{array}$ & $\begin{array}{l}\text { Over- } \\
\text { ail } \\
\text { Cond1- } \\
\text { tons }\end{array}$ & $\begin{array}{l}\text { Age } \\
\text { Years }\end{array}$ & $\begin{array}{l}\text { Pelo- } \\
\text { city } \\
\text { ft. per } \\
\text { ginute }\end{array}$ & $\begin{array}{l}\text { Insula- } \\
\text { tion } \\
\text { thlek-. } \\
\text { ness in. }\end{array}$ & $\begin{array}{l}\text { ripes. } \\
\text { Teanp: } \\
\text { of }\end{array}$ & $\begin{array}{l}\text { Sur- } \\
\text { farse } \\
\text { 'tengy } \\
\text { of }^{-} \\
\end{array}$ & $\begin{array}{l}\text { Me an } \\
\text { 'Peiny" } \\
\text { OF' }\end{array}$ & 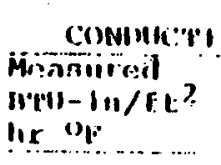 & 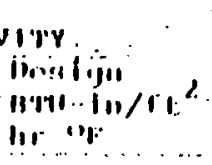 \\
\hline 1 & 1 . & 4 & 2 & 20. & 50 & 1.63 & 267.08 & 123.52 & $195.4^{\circ}$ & 0.3989 & 0.4106 \\
\hline $1 \cdots$ & 1 & 4 & 2 & 20. & 100 & 1.63 & 266.90 & 128.36 & 197.6 & 0.4131 & 0.4113 \\
\hline 1 & 1 & 4 & 2 & 27. & 100 & $=2.19$ & $281: 12$ & 119.48 & 200.3 & 0.3951 & 0.4121 \\
\hline 1 & 1 & 4 & 2 & 27. & 100 & $2: 19$ & 280.94 & 122.18 & 201.6 & 0.4330 & 0.4125 \\
\hline 1 & 1 & 4 & 2 & 15 & 50. & 1.66 & $286: 16$ & 126.15 & 206.2 & 0.3511 & 0.4139 \\
\hline 3 & 1 & 3 & 1 & 2. & 150 & 2.65 & 345.02 & 96.26 & 220.6 & 0.4018 & 0.4184 \\
\hline 3 & 1 . & 3 & $\mathbf{1}$ & 2 & 150 & 2.65 & 347.00 & 95.90 & 221.4 & 0.4059 & 0.4186 \\
\hline 3 & 4 & 3 & 3 & 15. & 0 & 1.63 & $347: 36$ & $96.26:$ & 221.8 & 0.3085 & 0.4188 \\
\hline 2 & 1 & 4 & 1 & 2. & 50 & $2: 04$ & 323.96 & $124: .3 !$ & $224: 2$ & 0.4076 & 0.4195 \\
\hline 2 & 1 & 4 & 1 & 2. & 7. & 2.04 & 330.08 & $118.7=$ & 224.4 & 0.4143 & 0.4196 \\
\hline 2 & 1 & 4 & 1 & 2 . & 50. & 2.04 & 325.94 & 123.80 & 224.9 & 0.3948 & 0.4197 \\
\hline 2 & 1 & 4 & 1 & 2. & 50 & 2.04 & 329.54 & 120.71 & 225.1 & 0.3959 & 0.4198 \\
\hline .3 & 2 & 3 & 2 & 15. & 100 & 1.63 & 348.26 & 113.00 & 2.30 .8 & 0.4527 & 0.4216 \\
\hline 1. & 1 & 3 & 2 & 15. & 0 & .1 .04 & 351.32 & $154.41]$ & $252: 9$ & 0.3132 & 0.4293 \\
\hline 1 & 1 & 3 & 2 & 15. & 0 & 1.02 & 346.64 & $161.0 \equiv$ & 253.9 & 0.3067 & 0.4297 \\
\hline i & 1 & 2 & 4 & 2 . & 0 & 2.01 & 410.36 & 116.24 & $263: 3$ & 0.2619 & 0.4331 \\
\hline 1 & 1 & 4 & 2 & 27 & 80 & 2.28 & 423.14 & $132.6 \bar{z}$ & 277.9 & 0.4564 & 0.4386 \\
\hline 1 & 1 & 4 & 2 & 27 & 50 & 2.20 & 423.14 & $139.8 \bar{e}$ & 281.5 & 0.4804 & 0.4400 \\
\hline 1 & 1 & 4 & 1 & 0.2 & 50 & 2.04 & 473.36 & $120.9=$ & 297.1 & 0.3246 & 0.4463 \\
\hline 1 & 1 & 4 & $\mathbf{L}$ & 0.2 & 50 & 2.04 & 474.98 & 123.62 & 299.3 & 0.3322 & 0.4471 \\
\hline 1 & 1 & 4 & 1 : & 0.2 & 100 & 2.03 & 560.84 & $110 \ldots$ & 335.7 & 0.4225 & $0.4628^{\circ}$ \\
\hline
\end{tabular}


TABI.E 7 (cont.)

DATA FOR CALCIUN SILICATE INSULATION

\begin{tabular}{|c|c|c|c|c|c|c|c|c|c|c|c|c|}
\hline \multirow{2}{*}{\multicolumn{2}{|c|}{$\begin{array}{l}\text { Jacket } \\
\text { Type } \\
\end{array}$}} & \multirow[b]{2}{*}{$\begin{array}{l}\text { Temp. } \\
\text { Var1- } \\
\text { áb111 ty }\end{array}$} & \multirow[b]{2}{*}{$\begin{array}{l}\text { Env I ror - } \\
\text { ment }\end{array}$} & \multirow{2}{*}{$\begin{array}{l}\text { Over- } \\
\text { all } \\
\text { Cond1- } \\
\text { tlons } \\
\end{array}$} & \multirow[b]{2}{*}{$\begin{array}{l}\text { nge } \\
\text { Years }\end{array}$} & \multirow{2}{*}{$\begin{array}{l}\text { Velo- } \\
\text { city } \\
\text { ft. per } \\
\text { minute }\end{array}$} & \multirow{2}{*}{$\begin{array}{l}\text { Insula- } \\
\text { t.lon } \\
\text { thick- } \\
\text { ness.In. }\end{array}$} & \multirow[b]{2}{*}{$\begin{array}{l}\text { Plpe } \\
\text { Yemp. } \\
\text { Op }^{*}\end{array}$} & \multirow{2}{*}{$\begin{array}{l}\text { Sur- } \\
\text { faree } \\
\text { I'cmp } \\
\text { OF }\end{array}$} & \multirow[b]{2}{*}{$\begin{array}{l}\text { Mrenu } \\
\text { Tremp } \\
\text { op }\end{array}$} & \multicolumn{2}{|c|}{ 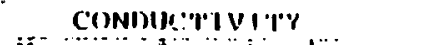 } \\
\hline & & & & & & & & & & & 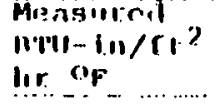 & 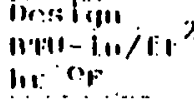 \\
\hline 3 & & 4 & 3 & 1 & 2. & 100 & 3.71 & 593.78 & 112.64 & .353 .2 & 0.3977 & 0.4709 \\
\hline 3 & & 9 & 3 & 1 & 2 . & 100 & 3.71 & 593.78 & 114.26 & 354.0 & 0.4025 & 0.4713 \\
\hline 1 & & 1 & 4 & 1 & 0.2 & 225 . & 3.08 & 605.66 & 125.24 & .365 .5 & 0.4209 & 0.4768 \\
\hline 3 & & 1 & 4 & 3 & 15 . & 250 & 4.92 & 761.18 & 116.96 &.$\quad 439.1$ & 0.3955 & 0.5157 \\
\hline 1 & & 1 & 4 & 3 & 15. & 250 & 4.89 & 761.18 & 128.12 & 444.6 & 0.7065 & 0.5189 \\
\hline 1 & & 1 & 4 & 2 & 15. & 0 & 5.04 & 839.66 & 136.76 & $488: 2$ & 0.5418 & 0.5451 \\
\hline .1 & $\cdot$ & 1 & .3 & 1 & 17. & 160 & 5.01 & 845.78 & 141.41 & 493.6 & 0.5855 & $0: 5485$ \\
\hline 1 & . & 1 & 3. & 1 & 17. & 175. & 5.03 & 850.46 & 145.04 & 497.8 & 0.5804 & 0.5511 \\
\hline 1 & . & 1 & 3 & 2 & 17. & 200 & 5.03 & 844.52 & 151.34 & 497.9 & 0.5561 & 0.5513 \\
\hline 1 & & 1 & 4. & 3 & 15. & 0 & 5.16 & 861.26 & $135: 50$ & 498.4 & 0.5359 & 0.5515 \\
\hline 1 & . & 1 & 3 & 2 & 17. & 200 & 5.03 & 846.86 & 163.40 & 505.1 & 0.6927 & 0.5559 \\
\hline 1 & & 1 & 3 & 1 & 17. & 160. & 5.09 & 869.54 & 141.62 & .505 .6 & 0.5223 & 0.5562 \\
\hline 1 & & 1 & 3 & 3 & 17. & 100 & 5.05 & 876.56 & 134.96 & 505.8 & 0.7156 & 0.5563 \\
\hline 1 & & 1 & 3 & 1 & 17. & 160 & 5.08 & .869 .54 & 148.46 & $509: 0$ & 0.5865 & 0.5584 \\
\hline 1 & & 1 & 3 & 2 & 17 & 125 & 5.04 & .879 .98 & 139.28 & 509.6 & 0.7975 & 0.5588 \\
\hline 1 & & 1 & 3 & 2 & 17. & 120 & 4.94 & 882.32 & 137.84 & 510.1 & 0.5856 & 0.5591 \\
\hline 1 & $\cdots$ & 1 & 3 & 2 & 17. & .100. & 4.94 & 878.72 & $142: 34$ & 510.5 & 0.6160 & 0.5594 \\
\hline 1 & & 1 & 3 & 2 & 17. & 150 & .4 .92 & $878: 72$ & 144.14 & 511.4 & 0.6778 & $0: 5600$ \\
\hline 1 & & 1 & 4 & 2 & 15 & 100 & 4.00 & 870.62 & 161.78 & 516.2 & 0.4811 & $0.563:$ \\
\hline 1 & & 1 & 3 & 2 & 17. & 110. & 4.94 & 891.50 & 141.26 & 516.4 & 0.6281 & 0.5632 \\
\hline $\mathbf{1}$ & $\therefore$ & 1 & 4 & 2 & 15. & 100 & 4.00 & 876.56 & 161.42 & 519.0 & 0.4843 & 0.5649 \\
\hline 1 & & 1 & 4 & 2 & 15. & 100 & 5.02 & 882.32 & 165.92 & 524.1 & 0.9137 & 0.5683 \\
\hline $\mathbf{1}$ & & 1 & 4 & $\dot{2}$ & 15. & 100 & 5.02 & 885.74 & $167: 00$ & 526.4 & 0.8998 & 0.5698 \\
\hline
\end{tabular}


TABLE 8

\section{ANALYSIS OF VARIANCE}

a) For insulation types, difference between measured and expected

$\begin{array}{lcccc}\text { Sources of Variation } & \begin{array}{l}\text { Degrees of } \\ \text { Freedom }\end{array} & \begin{array}{l}\text { Sums of } \\ \text { Squares }\end{array} & \begin{array}{l}\text { Mean } \\ \text { Square }\end{array} & \text { F. Ratio } \\ \text { Among insulations } & 2 & 0.1520 & 0.0760 & 4.15 \\ \text { Within insulations } & 88 & 1.6118 & 0.0183 & \\ \text { Total } & 90 & 1.7638 & \end{array}$

b) For insulation type, for measured conductivities

$\begin{array}{lcccc}\text { Sources of Variation } & \begin{array}{l}\text { Degrees of } \\ \text { Freedom }\end{array} & \begin{array}{l}\text { Sums of } \\ \text { Squares }\end{array} & \begin{array}{l}\text { Mean } \\ \text { Square }\end{array} & \text { F Ratio } \\ \text { Among insulations } & 2 & 1.6490 & 0.8245 & 27.85 \\ \text { Within insulations } & 88 & 2.6113 & 0.0296 & \\ \text { Total } & 90 & 4.2556 & & \end{array}$

c), For insulation and age, for measured conductivities

$\begin{array}{lccccc}\text { Sources of Variation } & \begin{array}{l}\text { Degrees of } \\ \text { Freedom }\end{array} & \begin{array}{l}\text { Sums of } \\ \text { Squares }\end{array} & \begin{array}{l}\text { Mean } \\ \text { Square }\end{array} & \text { F Ratio } \\ \text { Among Insulations } & 2 & 1.0181 & 0.5090 & 15.8 \\ \text { Among ages } & 2 & 0.2174 & 0.1087 & 3.37 \\ \text { Ingulation and ages } & 4 & 0.3111 & 0.0778 & 2.42 \\ \text { Error } & 57 & 1.8364 & 0.0322 & . \\ \text { Total } & 65 & 3.3830 & & .\end{array}$


None of the other categorical variables (jacket type, temperature variability, environment or overall condition) gave significant results when analyzed in this manner.

Further analyses were made to determine if any of the variables had a direct effect upon the measured conductivity. The results of this analysis for insulation types can be found in Table $8 \mathrm{~b}$. As was expected, the $F$ ratio was highly significant and further calculations show that calcium silicate had the highest average measured conductivity, followed by mineral fiber and then glass fiber. Due to the large effect which insulation type has upon the measured conductivity, it was necessary in evaluating the influence of the variables to study them together with insulation type. For example, to study whether insulation age has an effect upon the measured conductivities, the ages used in the analysis were those for which observations of all the insulations were available. This occurred for insulations having ages two, fifteen and seventeen years and included sixtysix values in all. The results of this analysis can be found in Table 8c. As before, differences in the measured conductivity aue to insulation type are significant. Also, there was a real difference between those conductivities of two years and seventeen years of age, but those with an age of fifteen years were not significantly different from either of the others. The third factor (i.e., insulation and age) was not significant indicating that the different insulations did not react differently at different ages. Similarly, in examining the possible effect which the different jackets might have had upon the measured conductivities, the all-service jacket produced significantly lower conductivity values than the other jackets. As expected, temperature also correlated strongly with the conductivity value. The remaining variables did not appear significant.

5.4.3 Regression-anaiysis - In order to determine which factors might explain the difference between the measured and the expected conductivities, a linear regression analysis was performed as an adjunct to the analysis of variance performed on the categorical variables: This type of analysis was 
performed on all of the data (Table 9) and the data on the calcium silicate insulation (Table 10), the glass fiber insulation (Table 11; and the mineral fiber insulation (Table 12). For the entire data set the difference between the measured and expected thermal conductivities is significantly correlated with the insulation thickness, pipe temperature, surface temperature and mean temperature. These correlations are not high but they are large enough to conclude that for each of these variables, an increase in the variable tends to show an increase in the difference between measured and expected conductivity values. The other factors do not show any relationship. For calcium silicate, the same relationships existed. For the other insulations, however, there was no significant correlation.

\subsection{Moisture Results}

A shortcoming of this study was the inability to obtain reliable moisture data in the field. The sensitivity of the device used was such that results below four percent moisture by weight were not observable. Since all of the insulations tested. were below this no data was obtained. 
TABLE 9

CORRFI.ATION MATRIX - ALL INSULATIONS

\begin{tabular}{|c|c|c|c|c|c|c|c|c|c|c|c|c|}
\hline Variable & Difforence & Jucket & $\begin{array}{l}\text { Insula-: } \\
\text { tlon }\end{array}$ & $\begin{array}{c}\text { ture } \\
\text { Vari- } \\
\text { abli1ty }\end{array}$ & $\begin{array}{l}\text { Fnvi ron- } \\
\text { ment }\end{array}$ & $\begin{array}{l}\text { all } \\
\text { Cond 1- } \\
\text { tion }\end{array}$ & $\underline{\text { nge }}$ & $\begin{array}{l}\text { Air } \\
\text { Velo- } \\
\text { city }\end{array}$ & $\begin{array}{l}\text { lation } \\
\text { Thlck- } \\
\text { ness }\end{array}$ & $\begin{array}{l}\text { Plpe } \\
\text { Tenuer - } \\
\text { ature }\end{array}$ & $\begin{array}{l}\text { Surfarse } \\
\text { Temper- } \\
\text { ature }\end{array}$ & $\begin{array}{l}\text { Menil } \\
\text { Irenime }- \\
\text { ature" }\end{array}$ \\
\hline Difference & 1.000 & -0.0472 & -0.0368 & 0.0816 & -0.0605 & 0.1199 & 0.1904 & 0.17960 & 0.6177 & 0.5057 & 0.2851 & 0.4980 \\
\hline Jacket & -0.0472 & 1.000 & 0.4113 & 0.4560 & -0.1602 & -0.0762 & -0.5422 & 0.0975 & -0.0276 & -0.2785 & -0.5958 & $-0.31 \cdot 30$ \\
\hline Insulation & -0.0368 & 0.4113 & 1.000 & 0.1245 & -02363 & 0.1210 & -0.2415 & 0.0569 & -0.2937 & -0.3019 & -0.3283 & -0.3113 \\
\hline $\begin{array}{l}\text { Temperature } \\
\text { Variability }\end{array}$ & 0.0816 & 0.4560 & 0.1245 & 1.000 & -0.1991 & 0.1948 & -0.1187 & -0.2203 & 0.05552 & 0.1080 & -0.0168 & 0.0995 \\
\hline $\begin{array}{l}\text { Environ- } \\
\text { ment }\end{array}$ & -0.0605 & -0.1602 & -0.2363 & -0.1991 & 1.000 & 0.0068 & 0.0863 & -0.2927 & -0.2038 & -0.1275 & 0.0726 & -0.1129 \\
\hline $\begin{array}{l}\text { Overall } \\
\text { Cond } 1 \text { tion }\end{array}$ & 0.1199 & -0.0762 & 0.1210 & 0.19 .48 & .0 .0068 & 1.000 & 0.3919 & -0.1249 & 0.1017 & 0.2201 & 0.2013 & 0.2236 \\
\hline Age & 0.1904 & -0.5422 & -0.2415 & 0.1187 & 0.0863 & 0.3919 & 1.000 & 0.0954 & 0.1563 & 0.3237 & 0.4691 & 0.3441 \\
\hline $\begin{array}{l}\text { Air } \\
\text { Velocity. }\end{array}$ & 0.1796 & 0.0975 & 0.0569 & -0.2203 & $-0: 2927$ & -0.1249 & 0.0954 & 1.000 & 0.4405 & 0.2919 & -0.0249 & 0.2707 \\
\hline $\begin{array}{l}\text { Insulation } \\
\text { Thickmess }\end{array}$ & 0.6177 & -0.0276 & -0.2937 & 0.0552 & -0.2038 & 0.1017 & 0.1563 & 0.4405 & 1.000 & 0.8201 & 0.3289 & 0.7959 \\
\hline $\begin{array}{l}\text { Pipe } \\
\text { Temperature }\end{array}$ & 0.5057 & -0.2785 & -0.3019 & 0.1080 & $-0: 1275$ & $0 . .2201$ & 0.3237 & 0.2919 & 0.8201 & 1.000 & 0.7144 & 0.9981 \\
\hline $\begin{array}{l}\text { Surface } \\
\text { Temperature }\end{array}$ & 0.2851 & -0.5958 & -0.3283 & -0.0168 & 0.0726 & 0.2013 & 0.4691 & -0.0249 & 0.3289 & 0.7144 & 1.000 & 0.7563 \\
\hline $\begin{array}{l}\text { Mean } \\
\text { Temperature }\end{array}$ & 0.4980 & -0.3130 & -0.3113 & 0.0995 & -0.1129 & 0.2236 & 0.3441 & 0.2707 & 0.7959 & 0.9981 & 0.7563 & 1.000 \\
\hline
\end{tabular}


TABLE 10

CORRELATION MATPIX - CALCIUM SILICATE

\begin{tabular}{|c|c|c|c|c|c|c|c|c|c|c|c|}
\hline Varlable & Difference & Jacket & $\begin{array}{l}\text { Temper- } \\
\text { ature } \\
\text { Vari- } \\
\text { ability }\end{array}$ & $\begin{array}{l}\text { Envi ron- } \\
\text { ment }\end{array}$ & $\begin{array}{l}\text { Over- } \\
\text { all } \\
\text { Cond1- } \\
\text { tlon }\end{array}$ & Age & $\begin{array}{l}\text { Air } \\
\text { Velo- } \\
\text { city } \\
\end{array}$ & $\begin{array}{l}\text { Insula- } \\
\text { tion } \\
\text { Thick- } \\
\text { ness }\end{array}$ & $\begin{array}{l}\text { Pipe } \\
\text { Temper- } \\
\text { ature } \\
\end{array}$ & $\begin{array}{l}\text { Surface } \\
\text { Tempera- } \\
\text { ture : } \\
\end{array}$ & $\begin{array}{l}\text { Mean } \\
\text { Temper- } \\
\text { ature }\end{array}$ \\
\hline DIfference & 1.000 & -0.2927 & -0.2234 & 0.0869 & 0.1199 & 0.3518 & 0.3532 & $0: 6236$ & 0.5644 & 0.4792 & 0.5732 \\
\hline Jacket & -0.2927 & 1.000 & 0.6319 & 0.0554 & .0 .1553 & -0.4418 & 0.0313 & $-0: 2287$ & -0.3508 & -0.6682 & -0.3826 \\
\hline $\begin{array}{l}\text { Temperature } \\
\text { Variabil1ty }\end{array}$ & -0.2234 & 0.6319 & 1.000 & -0.1625 & -0.0283 & -0.0283 & -0.1312 & $-0: 1037$ & -0.1283 & -0.3900 & -0.1504 \\
\hline $\begin{array}{l}\text { Environ- } \\
\text { ment }\end{array}$ & 0.0869 & -0.0554 & -0.1625 & 1.000 & 0.1525 & 0.2164 & 0.3089 & -0.1282 & -0.1571 & $0: 0553$ & -0.1461 \\
\hline $\begin{array}{l}\text { Overall } \\
\text { Condition }\end{array}$ & 0.1199 & -0.1533 & -0.0283 & 0.1625 & 1.000 & .0 .4586 & -0.1646 & 0.1257 & 0.1327. & 0.1282 & 0.1359 \\
\hline Age & 0.3518 & -0.4418 & -0.2083 & 0.2164 & 0.4586 & .1 .000 & 0.1167 & 0.2455 & .0 .2165 & 0.4522 & 0.2391 \\
\hline $\begin{array}{l}\text { Afr } \\
\text { Velocity }\end{array}$ & 0.3532 & 0.031 .3 & -0.1312 & -0.3089 & -0.1546 & 0.1167 & 1.000 & 0.5397 & 0.4645 & 0.0922 & 0.4502 \\
\hline $\begin{array}{l}\text { Insulation } \\
\text { Thickness }\end{array}$ & 0.6236 & -0.2287 & -0.1037 & -0.1282 & 0.1257 & 0.2455 & 0.5597 & 1.000 & 0.9495 & 0.4773 & 0.9409 \\
\hline $\begin{array}{l}\text { Surface } \\
\text { Temperature }\end{array}$ & 0.4792 & -0.6682 & -0.3900 & 0.0553 & 0.1 .282 & 0.4522 & 0.0922 & .0 .4773 & 0.6069 & $1: 000$ & 0.6509 \\
\hline $\begin{array}{l}\text { Mean } \\
\text { Temperature }\end{array}$ & 0.5732 & -0.3826 & -0.1504 & -0.1461 & 0.1359 & 0.2391 & 0.4502 & 0.9409 & 0.9984 & 0.6509 & 1.000 \\
\hline
\end{tabular}


TABLE 11

CORREIATTON MATRIX - GLASS FIBER

\begin{tabular}{|c|c|c|c|c|c|c|c|c|c|c|c|}
\hline Varlable & Difference & Jacket & $\begin{array}{l}\text { ature } \\
\text { vari- } \\
\text { ability }\end{array}$ & $\begin{array}{l}\text { Envitron- } \\
\text { ment }\end{array}$ & $\begin{array}{l}\text { all } \\
\text { Cond1- } \\
\text { tion }\end{array}$ & Age & $\begin{array}{l}\text { Alr } \\
\text { Velo- } \\
\text { city }\end{array}$ & $\begin{array}{l}\text { ton } \\
\text { Thick- } \\
\text { ness }\end{array}$ & $\begin{array}{l}\text { Pipr } \\
\text { Temper- } \\
\text { ature }\end{array}$ & $\begin{array}{l}\text { Surfiace } \\
\text { Tempera- } \\
\text { ture }\end{array}$ & $\begin{array}{l}\text { Mranl } \\
\text { Temper- } \\
\text { ature }\end{array}$ \\
\hline DIfference & 1.000 & 0.2076 & 0.0465 & $-0: 2600$ & -0.0777 & 0.0048 & 0.0251 & 0.2678 & -0.0241 & -0.2552 & -0.0612 \\
\hline Jacket & 0.2076 & 1.000 & -0.0531 & -0.1869 & -0.4662 & -0.5971 & 0.4157 & 0.4601 & -0.0022 & -0.1938 & -0.0326 \\
\hline $\begin{array}{l}\text { Temperature } \\
\text { Variability }\end{array}$ & 0.0465 & -0.0531 & 1.000 & -0.2993 & 0.3160 & $0: 0752$ & $-0: 3619$ & -0.1791 & 0.2896 & 0.3263 & 0.30 .31 \\
\hline Environment & $=-0.2600$ & -0.1869 & -0.2993 & 1.000 & -0.0868 & -0.1300 & -0.2170 & -0.5469 & 0.1850 & 0.3586 & 0.2171 \\
\hline $\begin{array}{l}\text { Overall } \\
\text { Condltion }\end{array}$ & -0.0777 & -0.4662 & 0.3160. & -0.0868 & 1.000 & 0.5602 & -0.2270 & -0.1303 & 0.3825 & 0.2691 & 0.3745 \\
\hline Age & $0.004 \mathrm{~B}$ & -0.5971 & 0.0752 & -0.1300 & 0.5602 & 1.000 & 0.0100 & -0.2209 & -0.2229 & -0.1522 & -0.2176 \\
\hline $\begin{array}{l}\text { Air Velo- } \\
\text { city }\end{array}$ & 0.0251 & 0.4157 & -0.3619 & -0.2470 & -0.22 .70 & 0.0100 & $1.000^{\circ}$ & 0.7482 & -0.1928 & -0.5491 & -0.2591 \\
\hline $\begin{array}{l}\text { Insulation } \\
\text { Thickness }\end{array}$ & 0.2678 & 0.4601 & -0.1791 & -0.5469 & -0.1303 & -0.2209 & 0.7482 & 1.000 & 0.0465 & -0.4129 & -0.0248 \\
\hline $\begin{array}{l}\text { Plpe } \\
\text { Temperature }\end{array}$ & -0.0241 & -0.0022 & 0.2896 & 0.1850 & 0.3825 & -0.2229 & -0.1928 & 0.0465 & $1: 000$ & 0.8078 & 0.9957 \\
\hline $\begin{array}{l}\text { Surface } \\
\text { Temperature }\end{array}$ & -0.2552 & -0.1938 & 0.3263 & 0.3586 & 0.2691 & -0.1522 & -0.5491 & -0.4129 & 0.8078 & 1.000 & 0.8592 \\
\hline $\begin{array}{l}\text { Mean } \\
\text { Temperature }\end{array}$ & -0.0612 & -0.0326 & 0.3031 & 0.2171 & 0.3745 & -0.2176 & -0.2541 & -0.0248 & 0.9957 & 0.8592 & 1.000 \\
\hline
\end{tabular}


TABLE 12

CORRELATION MATRIX - MINERAL FIBER

\begin{tabular}{|c|c|c|c|c|c|c|c|c|c|c|}
\hline Variable & Difference & Jacket & $\begin{array}{l}\text { Temper- } \\
\text { ature } \\
\text { Varl- } \\
\text { ability }\end{array}$ & $\begin{array}{l}\text { Over- } \\
\text { all } \\
\text { Cond1- } \\
\text { tion } \\
\end{array}$ & Age & $\begin{array}{l}\text { Air } \\
\text { Velo- } \\
\text { city }\end{array}$ & $\begin{array}{l}\text { Insula- } \\
\text { tion } \\
\text { Thick- } \\
\text { ness }\end{array}$ & $\begin{array}{l}\text { Plpe } \\
\text { Tenper- } \\
\text { ature } \\
\end{array}$ & $\begin{array}{l}\text { Surface } \\
\text { Tempera- } \\
\text { ture } \\
\end{array}$ & $\begin{array}{l}\text { Mean } \\
\text { Tempera- } \\
\text { ture }\end{array}$ \\
\hline Difference & 1.000 & 0.3820 & 0.6501 & 0.1971 & -0.4516 & -0.3182 & $0: 6824$ & 0.3098 & 0.0246 & 0.2851 \\
\hline Jacket & 0.3820 & 1.000 & 0.4369 & 0.1778 & -0.6599 & -0.1322 & 0.7393 & -0.0207 & -0.6701 & -0.1507 \\
\hline $\begin{array}{l}\text { Temperature } \\
\text { Variability }\end{array}$ & 0.6601 & 0.4359 & 1.000 & 0.4836 & -0.0659 & -0.3833 & 0.5994 & 0.6048 & 0.2368 & 0.5812 \\
\hline $\begin{array}{l}\text { Overall } \\
\text { Condition }\end{array}$ & 0.1971 & 0.1778 & 0.4836 & 1.000 & 0.1625 & 0.0371 & 0.2750 & 0.5659 & 0.4005 & $0: 5671$ \\
\hline Age & -0.4216 & $-0.62 \cdot 9.9$ & -0.0659 & 0.1625 & 1.000 & 0.0859 & -0.7023 & 0.2046 & 0.5922 & 0.2630 \\
\hline Air Velocity & -0.3182 & -0.1333 & 0.3833 & 0.0371 & 0.0859 & 1.000 & -0.0659 & 0.2619 & 0.0968 & $0: 2692$ \\
\hline $\begin{array}{l}\text { Insulation } \\
\text { Thickness }\end{array}$ & 0.6824 & 0.7393 & 0.5994 & 0.2750 & -0.7023 & -0.0659 & 1.000 & 0.4074 & -0.2516 & 0.3382 \\
\hline $\begin{array}{l}\text { Pipe } \\
\text { Temperature }\end{array}$ & 0.3098 & -0.0207 & 0.6048 & 0.5659 & 0.2046 & $0.281 \mathrm{~s}$ & 0.4074 & 1.000 & 0.6548 & 0.9952 \\
\hline $\begin{array}{l}\text { Surface } \\
\text { Temperature }\end{array}$ & 0.0246 & -0.6701 & 0.2368 & 0.4005 & 0.5922 & $0.096 \mathrm{E}$ & -0.2516 & 0.6548 & $1: 000$ & 0.7257 \\
\hline $\begin{array}{l}\text { Mean } \\
\text { Temperature }\end{array}$ & 0.2851 & -0.1057 & 0.5812 & 0.5671 & 0.2630 & $0.269 z$ & 0.3382 & 0.9952 & 0.7257 & 1.000 \\
\hline
\end{tabular}




\subsection{CONCLUSIONS}

\subsection{Overview}

The major conclusion of this study is that there is a significant difference between the thermal conductivity values expected from the manufacturer's data (as supplied in Reference 1) and those values which were measured. Furthermore, this difference did not correlate significantly with any of the factors which could have reasonably been thought to cause insulation deterioration. Another conclusion of this study is that heat flow meters appear to be viable devices for the field measurement of heat flow. The calibration results of this type of instrument against the industry's standard method of measuring thermal conductivity shows a high degree of correlation indicating that a high degree of precision and accuracy is achievable.

\subsection{Discussion}

The difference between the measured and expected thermal conductivities could be explained in any one of four ways:

1. The difference is real;

2. The difference is due to a bias in the measurements;

3. The difference is due to unreasonably low expected values for the conductivity;

4. The difference is due to moisture in the insulation.

The possibility of measurement errne is a real one, in particular, because the pipe temperature probe appeared to underestimate consistently the actual temperature. The magnitude of this inaccuracy however, would not sufficiently explain the difference. That unreasonable low expected values might account for the difference is a real possibility due primarily to two factors,

First, the values used for expected conductivities were supplied by the industry (Reference 1 ) and represent an average of various manufacturer's data. The variability of these numbers, therefore, could be high with respect to any given manufacturer's insulation. Also, as indicated previously, these average values 
were taken from relatively recent data and may not represent insulation conductivity values of past years. These average values were fitted into equations to predict conductivity changes with temperature and this could have resulted in still further error. Second, manufacturer's values are always presented on a dry basis. Moisture could have a profound effect on conductivity values even when present in low concentrations. Since it is reasonable to expect that moisture was present to some degree in most of the insulations tested in the field, it can be concluder that the possibility does exist that moisture was a causative factor. If such were the case, however, there should lave existed a negativo oorrolation between the difference between the two sets of values and the pipe, surface or mean temperatures since it can be assumed that the presence of moisture and, therefore, its effects, would decrease at a higher temperature. This did not occur. Hence it remains uncertain whether moisture was indeed a major factor in causing this difference.

In evaluating the effect of different variables on the difference between the expected and measured conductivity values there did not appear to be any firm or conclusive correlations. The correlation with insulation thlckness ard pipe, surface and mean temperatures were only marginally significant and point to either a physical effect (i.e., the larger the amount of insulation the more defnrmation) or a calculation phenomena (i.e., the expected value calculations are not accurate at higher temperatires). The factor analysis results appear spurious in light of the fact that differences between the insulations categorized as of two and fifteen years and fiftcen and seventeen years were not significant. Also, in view of the regression analysis the effects of age on insulation conductivities appear non-existent. 


\subsection{REFERENCES}

1. Economic Thickness for Industrial Insulation, Prepared by York Research Corporation, Stamford, Connecticut for Federal Energy Administration under contract No. CO-04-50169 GPO stock No. 041-018-00115-8, August 1976.

2. Industrial Thermal Insulation - An Assessment, Donnelly, R.G., Tennery, V.J., MCElroy, D.I., Godfrey; T.G. and J.O. Kolb. Oak Ridge National Laboratory, Oak Ridge; Tennessee. Prepared for Division of Buildings and Industry, Energy Research and Development Administration TID-27120

August 1976

3. Sales brochure of the Institute of Applied Physics, Delft, Netherlands, 1976. 


\title{
APPENDIX A \\ THERMAI CONDUCTIVITY INSTRUMENT \\ PIPE INSULATION
}

\author{
built for \\ YORK RESEARCH CORPORATION \\ Stamford, Connecticut
}

built by

SPARREIL ENGINEERING

RESEARCH CORPORATION

Salem, Massachusetts

June 7, 1977 
THERMAL CONDUCTIVITY INSTRUMENT -- PIPE INSULATION

This instrument has been designed and constructed to determine the Thermal Conductivity of Pipe Insulation. It conforms to: the ASTM Specification 335, and includes features not covered by the specification.

The principle is based on creating a section of an infinitively long pipe, over which a sample of the insulation whose thermal conductivity is desired, is placed. The power to an electrical heater rontained within this section of pipe is accurately measured, as well as the temperatures of the pipe (inside surface temperature of the insulation) and the outside insulation surface. These quantities, together with the geometry of the insulation (inside and outside radii), permit the thermal conductivity of the insulation to be calculated. To create the infinite geometry, the monitored section is confined axially (at each of its ends) by an independent guard heater, whose thermal conditions are controlled to negate any axial heat flow, thus insuring radial heat flow in the test zone and the infinite model to exist.

Basically, the instrument consists of two parts, the test section with its support frame, and a control console. The test section is mare up of a heavy wall stainless steel pipe, 3" nominal diameter, divided into 3 zones, a center $3^{\prime}$ main section, and 2, $I^{\prime}$ end or guard zones. A thermal break is. provided between each zone by a 3/16" wi.de gap machined circumferentially through the pipe wall. Three $3 / 8$ " long bridges at $120^{\circ}$ maintain physical continuity of the pipe. 
Contained within each of the 3 zones is an independent heater composed of an alumina core with a spiral external groove.

A heater wire is wourd in this groove and held in place with a ceramic cement. The heater cores are suspended concentrically within the stainless pipe by means of stainless steel set-screws at the ends of each heater. The heater leads extend through the center of the ceramic cores and out the ends of the stainless test pipe. The pipe is supported at each end by a i4-3/4" diameter transite disk, which in turn is supported on the steel test section support frame.

A total of 17 platinum versus platinum - 10\% rhodium (type s) thermocouples (0.010" diameter wire) are used to determine the temperature of the stainless pipe. Three are located at the axial midpoint and three at 6" in from the guard-main break at each end. These are distributed around the pipe circumference. The remaining eight are located in pairs, positioned, two pairs on each end, 1 " on either side of the guard-main break. The thermocouples are contained in high purity, double-bore alumina tubes and lie in grooves machined in the surface of the stainless steel test pipe. The junction, a welded heac, extends from the end of the ceramic tube and is held in place with a ceramic cement. The thermocouple leads extend from the tube at the ends of the stainless steel test pipe and go to screw terminals mounted on the transite and disks. Additional platinum and platinum-rhodium.wire leads from the screws to an ice reference Dewar flask where transition is made to copper wire. An additional nine platinum versus platinum $-10 \%$ rhodium thermocouples, of the same wire, are. 
provided for use in measuring the surface temperature of the insulation sample.

In operation (see following section) it is desirable to equate the temperatures across the break in the stainless test pipe and,ideally, it would be desireable to use the signal from the pairs of thermocouples on either side of the break to control the end heaters. This is not practical however, since the response time would be low, especially at low temperatures. Therefore, a separate system of thermocouples are provided to generate a signal for the automatic controllers provided to control the power to the end heaters. This system consists of 12 iron-constantan thermocouples, 6 at aach end. These are mounted on the external surfaces of the heater cores, in pairs, one of each pair attached to the main heater core, l" from the break on the guard heater. These 6 thermocouples are then attached in a clrcult to form a thcrmopile, with al.ternate thermocouples bucking each other. Thus a differential signal is generated, which when nulled, indicates that the main heater core, at a point that is 1 " from the break is identical in temperature to a point. $l^{\prime \prime}$ from the break in the guard heater core. The leads from these thermocouples are also fastened to screws located on the transite end plates.

Five voltage taps lead from the main heater winding to additional screw terminals on the transite plates. Two come from the ends of the main heater and 2 from a point l' from the guard-main heater break, thus permitting voltage measurements of the main heater in 3 equal length sections. The 5 th tap 
comes from the center of the core but is not used.

A single iron-constantan thermocouple extends to the center

$\therefore$ of the main heater and lies on the inner surface of the heater core. This thermocouple goes to the over-temperature controller and is used to set a predetermined maximum operational temperature for the test section.

Two small diameter stainless steel tubes extend the full length of the test section, one mounted in a groove in the stainless steel test pipe and the other, on the inner surfaces of the heater cores. These may be used for passing a traversing thermocouple along the full length of the test section to establish a complete temperature profile.

The second section of the test system is the control console. This is a bench mounted cabinet which houses the electrical circuits, the power relays, the guard heater controllers (2), the over-temperature controller, the main heater voltage divider and shunt, and the data acquisition switches. 
The sample to be tested should be mounted on the stainless steel test pipe, following the procedures normally used in the field and recomended by the manufacturer of the insulation. However, prior to mounting it, the sample should be inspected, and any irregularities, especially on the inner surface, should be noted. The inner surface should be clean and free from any particles, bumps or crevasses which would prevent the sample from making gond and uniform contact with the test pipe. Normally, a 3' long section of sample is mounted on the main heater section with. 2 I' long sections installed at each end. Avoid a gap at the interface of the sections which would pérmit direct radial radiation at this point.

The outside diameter should be carefully measured at several points and avelaged, after the sample has been installed. The 9 platinum versus platinum-108 rhodium sirface thermocouples should now be attached! to the outer surface of the insulation. The junctions should be distributed, both axially and radial1y, to provide a good representative average surface temperature (along the main heater section of the insulation). If the surface of the insulation is fabric covered, the thermocouples may be woven into the Eloth, otherwisc, paper masking. tape may be applied to hold the junctions and leads in place. The lead wire slose to the junction (an inch or so) should lie along the insulation surface, in good contact with it.

A dewar flask is provided to serve as an. ice-water, $32^{\circ}$ referenc 
for the thermocouples. This bottle should be filled with crushed ice and water. Be certain (at least when the final data is taken) that the bottle is filled with ice and not just ice floating on the water. Press down on the ice-water surface and if the ice submerges, additional ice should be added and water removed. In placing the cover containing the glass tubes and junctions in the dewar, work it into the ice gradually avoiding forces which would break the tubes. Also visually check the junctions to make sure that they are all located in the bottom of the tubes.

Prior to turning the Power on, a rough voltage setting for the main heater should be cálculated. This may be based on the desired pipe temperature and a rough estimate of the thermal conductivity of the test sample. The wattage may be determined by using the equation presented in a latter section for calculating the thermal conductivity, in reverse. Since the electrical resistance of the main heater is about 12.5 ohms, the voltage may be calculated as:

$$
\text { Voltage }=\text { Watts } \times 12.5
$$

The test is started by turning on the main power switch on the control console panel. Set the overtemperature controller at a temperature level higher than the anticipated pipe temperature. Remember that the controller utilizes a thermocouple mounted on the inner surface of the main heater ceramic core, and therefore, will indicate a temperature considerably higher $\left(100^{\circ} \mathrm{F}\right.$ or more) than the pipe temperature. Next turn on the main heater power switch and depress the adjusting.knob on 
the overtemperature controller. This will reset a latching relay in the controller and allow the heater circuits to remain on. Read and adjust the main heater voltage on the $D C$ power supply (external to the control console) to the desired level. The voltage is read by placing the 4 th (right) rotary selector switch on SW3 and the 3rd selector switch on V1. The signal then appearing on the potentiometer terminals represents the voltage across the entire main heater winding. The voltage divider network employed, produces 1 millivolt per volt, so that the reading in millivolts may bo considered to be the actual voltage.

Immediately after the main heater has been turned on, the guard heaters should also be turned on, using the guard heater power switch (left). This is done rlght away to keep the guard heaters close to the main heater in temperature, to avoid large thermal gradients and also to avoid an excessively large amount of power to be delivered to the guard heaters in a short period of time, if they were turned on while well below the main heater. The guard heaters will cycle on and off proportlunally as indicated by the small red lamp in each of the guard heater controllers. The signals going to these controllers, produced by the iron-constantan differential thermocouples (as discussed in the first section) may be read as D1 and D2 (left and right respectively) on selector switch 3 .

Thermal measurements are invariably very slow, and this is especially true of a pipe insulation tester. The thermal diffusivity of the typical test materials plus the ratio of 
the test section mass to the final energy dissipation of the heaters result in a very large time constant. To reach equilibrium can require a day or more and a multipoint test over an extended temperature, range can require a week or more. The test section must be at thermal equilibrium to produce good results. One thing that may be done to speed up the transient time is to increase the main heater voltage to a higher-than-final value, however, the temperatures should be monitored continually so that the voltage may be reduced as the desired point is reached. Under no circumstances allow the temperature to rise at a rate greater than $100^{\circ} \mathrm{F}$ per hour. To do so would produce excessive temperature gradients, especially in the heater core near the heater windings and could produce cracking due to thermal stresses.

Upon reaching a condition close to steady-state, at the desired temperature level, the guard heaters receive their final bias or trim adjustment. As discussed in the first section, the guard heaters should be balanced so as to equate the temperatures in the test pipe on either side of the guard-main break. This is done by adjusting the controllers so as to equate the temperatures as measured by the pairs of platinum versus platinum-108 rhodium thermocouples on either side of the break. If the section of the pipe external to the break is cold, bias the guard heater controller for that end by rotating the indicator knob clockwise. At high temperatures, the required bias may exceed the range of the indicator on the controlier. The controller differential thermocouple is made up of three pairs of iron-constantan thermocouples as previously discussed. The 
use of a single pair will reduce the signal to $1 / 3$ of the 3 pair thermopile. Actually, the 3 pairs may be wired in parallel rather than series, giving a good average that is $1 / 3$ of the original signal. These may be rewired at the terminals on the transite end plates.

Once the desired temperature level has been reached, the ends balanced, and all temperatures at an equilibrium, the data is taken to determine the thermal conductivity of the sample. The data consists of all thermocouple readings taken on the rotary selector switches, with the numbere oorresponding to the thermocouple locations, the 3 voltage readings, V1, V2, and $V 3$ on switch 3 , the current reading, $I$, and the differentlal signals DI and D2. (these last are not used in data reduction, but will be useful in future measurements).

The temperatures are converted from millivolts to ${ }^{\circ} F$ and the current converted frum millivolta to amps. The current shunt produces 5 miliivolts per amp. The equation used for caloulating the thermal conductivity of the pipe insulation is the following:

$$
\begin{aligned}
& Q=\frac{K(2 \pi L)\left(T_{1}-T_{2}\right)}{\ln \left(r_{2} / r_{1}\right)}, \\
\text { or: } & K=\frac{Q \ln \left(2 / r_{1}\right)}{2 \pi L\left(T_{1}-T_{2}\right)},
\end{aligned}
$$

where: $Q=$ Main heater power dissipation, Btu/hr

$$
=\text { volts }{ }^{*} \mathrm{X} \text { amps } \mathrm{X} 3.415, \mathrm{Btu} / \mathrm{hr} \text {-volts-amps }
$$$$
r_{2}=\text { outside radius of insulation, in. }
$$$$
r_{1}=\text { Inside radius of insulation, in. (1.75") }
$$ 


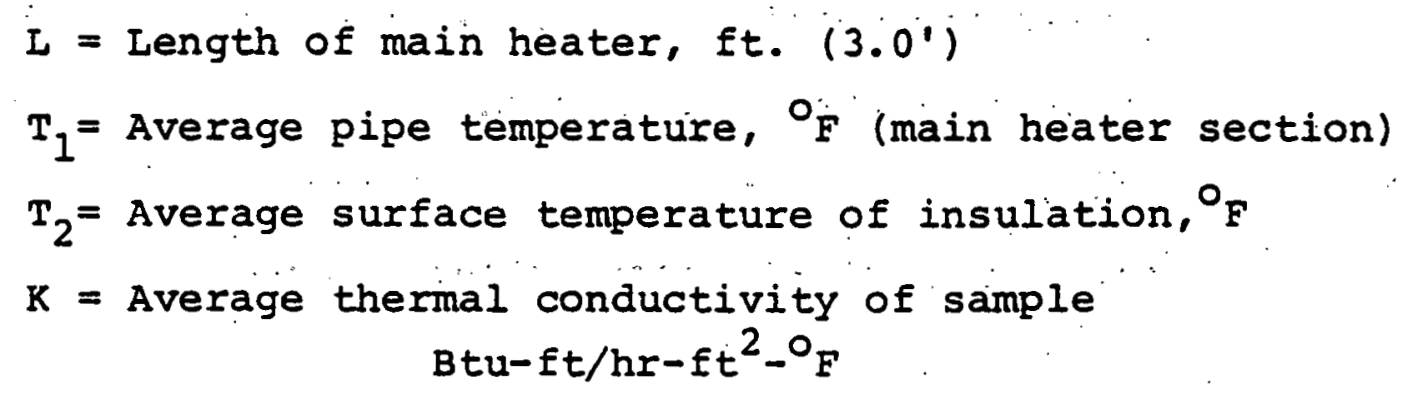

*Note: The total voltage Vl should be used if the total 3' leng.th is used. 


\section{ERROR ANALYSIS}

The primary goals during the design and construction of this instrument were to establish, first an instrument that was highly accurate with respect to the determination of the thermal conductivity of a sample of pipe insulation and second, an instrument which would generate a highly uniform and known radial heat flux. This latter feature was to permit the calibration of heat flux meters and to provide a test bed for the evaluation of methods and instrumentation for field surveys of pipe insulation.

An early analysis indicated that it was desirable to utilize a heavy wall pipe to produce a uniform axial temperature and thus provide a uniform heat flux radially. Both brass and stainless steel were considered, however, the slight gain in pipe temperature uniformity using brass was offset by the problems of oxidation and scaling of the brass at high temperatures (above $500^{\circ} \mathrm{F}$ ).

Whereas the ASTM specification C 335 permits a pipe length (total) of 3 feet, the high axial conduction of the heavy wall and the desire to meet the primary goals, lead to a total pipe length of 5 feet, with a 3 foot measurement section and 1 foot end guards.

It is difficult to predict an overall accuracy for an instrument such as this since, in general, it is the minor sources of error which may be tied down, well where as the larger errors are less predictable: In meeting the primary goals, it was 
decided to select the better of two choices whenever a decision about two components was made. For example, with the temperature measurements, platinum versus platinum-10\% rhodium thermocouples were selected rather than iron versus constantan or chromel versus alumel. With this decision, the question of thermocouple drift could be eliminated. Similarly, the best, with respect to stability, D-C power supply was selected for the. main heater. A shunt, which probably would have been accurate enough without calibration, was calibrated to insure maximum accuracy. Thermocouple extension wire was not used but rather the noble metal was extended right to the ice ref-. erence. A provision for traversing thermocouples was included, not that these were required, but rather, to permit detail investigations of axial uniformity, should this be required. Automatic controllers were used for the end guards, since these track more closely (and eliminate much labor) than could ever be achieved manually.

Looking at the accuracy of the instrument with respect to its use in thermal conductivity measurements, the terms which enter the calculation are the sample dimensions, $R_{1}, R_{0}$, $L$, the temperatures, $T_{1}, T_{0}$, and the power dissipation or heat flux of the main heater, $Q$.

\section{Dimensions}

The ASTM Specification C 335 suggests a determination of the insulation inside diameter by measuring the pipe wall with . calipers to the nearest $0.001 "$ at 6 places and averaging these values. If this were done, a typical number for accuracy on the inside diameter would be:

$$
\mathrm{A}-13
$$




$$
\frac{0.001}{3.5}=0.0003 \quad(0.038)
$$

FFor the sample outside diameter, the specification suggests a measurement by calipers again in 6 places to $1 / 32 "$. It is unlikely that a sample with less than a thickness of I" would be tested, thus the error would be less than:

$$
\frac{0.031}{5.5}=0.006 \quad(0.68)
$$

Also the length of the sample (main heater section) comes into the determination. 'The main heater is 3' long, however, there is a finite gap of $3 / 16$ " in the pipe wall at the interface. This dimension ( $1 / 2$ assigned to each end) is probably a good representation of the geometric uncertainty (as opposed to heater length discussed further on) in length.

$$
\frac{3 / 16}{3(12)}=0.005 \cdot(0.58)
$$

Temperature Measurements

Sources of error with respect to temperature measurements are: thermocouple installation, thermocouple calibration, ico reference, circuitry stray emf's, read-out. instrument, and ambient temperature variations.

Great care has been taken in the installation of the thermocouples in the tube wall. Grooves have been machined so that the wires will lie in an isothermal planc (parallel to the wall). It is true that the cement around the junction does distort the heat flux lines, however, the total gradient through the pipe wall is very small $\left(0.2^{\circ} \mathrm{F}\right.$ across the wall at a heat flux of $100 \mathrm{Btu} / \mathrm{hr}-f \mathrm{t}^{2}$ ). Thus, an error due to 
the installation of wall thermocouples can be considered small. Since the flux level is less at the outer radius of the insulation, the installation of the thermocouples on the outer surface is in some aspects, less critical than on the pipe wall. However, care should be taken in installing the outer surface thermocouples. The wire close to the junctions should lie along the insulation surface in contact. The wire is a small diameter, $(0.010 \%)$, thus the fin effect will be small. If a tape is used over the junction, it should be thin and have about the same radiation and surface texture properties as the insulation. Again the errors associated with the installation of the surface thermocouples should be small. In both locations, a total of 9 thermocouples are used and their values averaged. This not only averages the properties of the material but also will permit comparisons such that an obviously erroneous thermocouple may be deleted.

The largest error in temperature measurement (and probably one of the largest errors in the entire instrument) is due to thermocouple calibration. Platinum versus platinum-10\% rhodium was selected flrst, due to its long term stability, but also due to the care with which it is produced (being a noble metal and free from impurities). The only disadvantage (other than 1ts cost) is its low emf, which puts a burden on the read-out instrumentation and any problems associated with stray emf's. Manufacturers are notoriously conservative when giving accuracy limits on their wire. Most manufacturers 
or suppliers place a limit of accuracy on platinum rhodium thermocouples as $\pm 5^{\circ} \mathrm{F}$ to $1000^{\circ} \mathrm{F}$." If this number were taken at face value and applied to a test situation with a small temperature difference, say $100^{\circ} \mathrm{F}$, it would result in a 108 error. Fortunately, this is not realistic. First of all, the value quoted applies to a deviation from a standard emftemperature relationship for this wire. Normally, a deviation appears which is quite linear such that at $1000^{\circ} \mathrm{F}$ it could be as great as $5^{\circ} \mathrm{F}$ but at $32^{\circ} \mathrm{F}$ is zero, and if positive in. deviation, it remains positive. Since we are intereeted in temperature aifferences, a more realistic error, assuming a linear deviation, say with conditions of a hot face at $500^{\circ} \mathrm{F}$ and a cold face at $100^{\circ} \mathrm{F}$ might be:

$$
\frac{2.5-0.5}{400}=0.005 \quad(0.58)
$$

To insure that a situation like this exists, all thermocouples are made of identical wire and should they ever.require replacement, all should be replaced with identical wire.

When taking final data for a thermal conductivity determination, the ice-water reference dewar should be freshly iced (although allow 15 minutes or so, to permit subcooled ice to equilibrate with the water). If the dewar is not filled, such that the junctions are in water below floating ice, an error of 2 to $3^{\circ} \mathrm{F}$ can occur which can introduce an error in temperatire difference measurements, if the junctions are not at the same level. With a properly iced reference, no error should exist.

From the ice reference to the read-out instrument, the circuit 
is entirely copper and since copper is produced in high purity, parasitic emf's should be negligible. The readout device should exhibit an infinite impedence to the circuit so that at measurement, no current is drawn through the circuit. If this is the case, circuitry errors should be negligible. The thermocouple circuits have been cabled separate from the power circuits, both $A-C$ and $D-C$ to prevent induced signals.

Since the error associated with the readout is external to the system, the error associated with the readout can be continually reduced merely by using a more accurate readout instrument. Therefore no error has been placed on this but it will depend on the instrument selected.

Ideally the test section should be operated in a room with a constant ambient temperature and with no drafts. The insulation surface temperature will respond quickly to ambient changes while the remainder of the system will respond very slowly due to its large time constant. To illustrate this effect, if the ambient changes by $10^{\circ} \mathrm{F}$ with a pipe temperature of $500^{\circ} \mathrm{F}$, the surface will respond within minutes, changing by about the same amount as the ambient and producing an error of 2.5\%. This error can be reduced by monitoring the ambient temperature for a long.period of time and taking a reading only after the ambient has been stable. As an alternative, an entire set of readings can be taken periodically, say over a 24 hour period, at I hour intervals. Points are then compared and if the variations are small, the average 
can be used.

Heat Flux

The accuracy of the heat flux measurements used in the calcuLation depends on; the stability of the D-C power supply, the shunt, the voltage divider; non-uniformity in heater windings, errors associated with the voltage taps and heater leads, circuitry stray emf's, read-out instrumentation and deviation from the infinite pipe model (end effects).

The power supply selected for use with this instrument is probably one of the best commercially available with regard to stability. This, of course, is important due to the long time constant of the test section. The specifications are as follows:

$$
\begin{aligned}
& \text { Drift } 0.018 \text { ( } 8 \text { hours) } \\
& \text { Temperature } 0.018 \\
& \text { Line Variations } 0.0005 \% \\
& \text { Load Variations - not applicable } \\
& \text { Ripple } \quad 0.2 \mathrm{MV}
\end{aligned}
$$

The shunt with it's calibration: 0.058

Voltage divider network: $0.025 \%$ each $=0.05 \%$

Circuitry errors are negligible for the same reasons discussed undicr temperature measurements. Errors due to read-out may be reduced as discussed befuré, to as blall as desired. The same read-out instrument is used for thermocouple, voltage and current measurements: Errors due to non-uniformity of the heater windings should be negligible, since the wire it- 
self is very uniform in resistance as is the spiral groove in the ceramic core. Any minor irregularities of this nature, would spread out anyway giving an average of high accuracy.

There can be a slight error due to the positioning of the end voltage taps relative to the active end of the heater core and its winding. If we allow a $1 / 2$ " uncertainty (including not only the actual position of the tap, but also any heat generation outside the tap appearing as part of the main heater flux) the error, based on a 40.1 main heater wire length becomes:

$$
\frac{2 \times 1 / 2}{40 \times 12}=0.002
$$

The one remaining source of error is the deviation from the non-infinte model. Not only is it a highly complex model to analyze, but it is also dependent upon temperature level, heat flux and sample geometry. As previously mentioned, a 5' pipe with ' ' $^{\prime}$ end guards was selected to minimize (within practical limits) this error. Ideally we would like a situation with an adiabatic plane, normal to the axis of the pipe passing through the heater core, the pipe, and the insulation at the main-guard heaters interface. Under that condition, all heat generated in the main heater would pass radially through the pipe wall and insulation. Thus a compromise must be reached, wherein the test section is of reasonable length and the axial conduction error is small. once this is selected, then the guard heaters must be operated in such a manner as to minimize the effect of axial conduction. 
As a rough model, the main-guard interface consists of 3 axial flow paths; 1) heater core; 2) stainless steel pipe, and 3) the insulation. To compare these 3 paths, approximate values for axial conduction have been determined:

$$
\begin{aligned}
& \text { Q }_{\text {heater core }}=0.0374 \mathrm{~T} \\
& \text { Q }_{\text {steel pipe }}=0.585 \\
& \text { Q }_{\text {insulation }}=0.106 \mathrm{~T}
\end{aligned}
$$

These were based on interface boundaries confined 1 " on either side of the gap (selected since this is the location of the control. and pipe themocouples), on an operating pipe temperature of $500^{\circ} \mathrm{F}$, a $3^{\prime \prime}$ thick sample of insulation and reasonable though approximate thermal properties.

The largest of the 3 axial conduction terms is that for the pipe. This is the reason for suggesting (in the operational instructions) that the guard heaters be biased so as to equate Wie temperatures in the pipe wall on either side of the gap. In reality, what happens is that since the ends of the test section are cold relative to the interface, heat will flow axially away from the center in the guard section of the pipe and also in the insulation. To force a balance at the gap in the pipe wall, the guard heater must run hotter than the main heater, to produce the heat being lost axially in the pipe and insulation. Since the guard heater is running hotter than the main heater, some heat is flowing axially into the heater core from the end heater core. One set of data recently taken on the instrument indicates that at $400^{\circ} \mathrm{F}$ with a main heater dissipation of 60 watts $(205 \mathrm{Btu} / \mathrm{hr})$ a bias of: about $15^{\circ} \mathrm{F}$ is required on the guard control thermocouples to 
balance the temperatures in the pipe. Plugging this into the axial equation for the core:

$$
Q=0.037 .4 \text { (15) (X2ends) }=1.12 \mathrm{Btu} / \mathrm{hr}
$$

or an error when related to the main heater power of:

$$
\frac{1.12}{205}=0.005
$$

Now this is an over simplification, however, it does tend to indicate the magnitude of the errors which might appear. In all probability, a more exact analysis (including additional test data and perhaps a computer analysis) might indicate that a better balance might be produced by biasing the end heaters at a value somewhere between a balance on the core and a balance on the pipe probably favoring the pipe in the ratio of the conductance coefficients.

Thus to summarize, it is evident that the instrument and its component parts have been selected and designed to produce a highly accurate instrument. A couple of the larger errors, namely those due to sample length, thermocouple calibration, and to axial heat flow are the hardest to define. The preceding discussions are meant to indicate that the magnitude of errors are small, not to assign absolute values. Even if all of the errors are combined by simple addition, indicating none are random, but all in the same direction, a number of between 2 and 38 may be assigned for the overall accuracy of the instrument. Since the errorsiare in fact, random in direction, the accuracy may be better. 


\section{APPENDIX B}

\section{PREIIMINARY}

DRAFT REOPRT *

Pipe Tester Calculations with HEATINGS

S. H. Jury

J. P. Moore

D. I. MCElroy

April 21, 1977

\section{Contents:}

Introduction

The first set of HEATINGS Calculations

Brass Envelop

Stainless Steel Envelop 1

Stainless Steel Envelop 2

The second set of HEATINGS Calculations

Stainless steel Envelop 3

Conclusions

References

Tables 3

* This report has been modified to allow for the exclusion of certain Figures which were not legible. 


\section{PIPE TESTER CALCULATIONS WITH HEATINGS}

\section{INTRODUCTION}

The York Research Pipe Tester. was studied using the ORNL finite difference code HEATINGS. ${ }^{2}$ Drawings of the tester were used to map a quarter-section of the system to allow temperaturedistance calculations for a variety of input quantities. The mapped section was bounded by the pipe axis, the system midplane, the specimen outer surface, and the transite board at the extreme ends. The mapped system consigted of 20 oeparate regions, composed of eight different materials and their properties $3-10 \mathrm{with}$ two power density input regions. The temperatures were calculated for 1363 nodes in this map.

Initially the material properties were chosen to be representative but independent of temperature. The values selected are shown in Table 1. In the process of these calculations some of the materials and their properties were changed to study effects of alternate constructions on the pipe tester thermal behavior. Although the selection of temperature independent properties may seem unrealistic, it was found to provide a useful results comparison basis. In the case of the specimen, the midplane thermal conductivity could be calculated from the radial temperature profile; the main heater power density, and the radial heat flow equation:

$$
\lambda=\frac{P}{2 \pi I} \frac{\text { ln } r_{2} / r_{1}}{T_{1}-T_{2}}
$$

and compared to the input $\lambda$ value of 0.02 Btu.ft/(hr.ft ${ }^{2} 0^{\circ}$ F). In this equation $T_{1}$ and $T_{2}$ are temperatures calculated using HEATINGS at two radii $r_{1}$ and $r_{2}$, respectively. 
The general goal of these calculations was to evaluate the system performance for various input conditions. The main goal of any radial heat flow measurement system is to obtain pure radial heat flow as opposed to impure radial flow with an unwanted axial heat flow component which would yield an incorrect specimen thermal conductivity conductivity. For instance, if the guard power density is too low, the system ends run cold and some of the main power is leaked axially. This axial leakage reduces the radial heat flow, so the rem sulting radial temperature difference is decreased and the calculated thermal conductivity is too high. similarly if the guarding is excessive, axial heat flow adds to the main power, increases the radial temperature difference, and the calculated thermal conductivity is too low.

Because of the above-described effect on the initial calculation task was to obtain the proper guard power density (G2) for a given main power density (G1). For the HEATING5 calculations to be meaningful, the program convergence must reach an assigned level after a number of iterations. For simple systems a convergence of $10^{-8}$ is obtained after about 500 iterations. An early finding of this study is that the as-mapped York Research Pipe Tester is not a simple system and convergence to $10^{-7}$ may require over 4000 iterations. If a given convergence limtt has not been reached, each computer run will continue until about 2200 iterations are completed (or 280 seconds of CPU time). As the number of iterations increase, in general, convergence will occur and simultaneously 
one notes the specimen mean temperature and radial temperaturs profile change. The HEATING5 program allows a run on the system to be initiated at any given temperature and when this run is completed the next run can be initiated from the final temperatures of the first run. Thus for Run 1, an initial system at $700^{\circ} \mathrm{F}$ might be used and temperature calculated for each of the 1363 nodes for 2200 iterations. The output from this would be punched on cards to be used as initial temperatures in Run 2. In all of the calculations described belnw convergeice has boen sought for varlous power denejty levels for GI and G2. In many cases runs were concluded prior to obtaining the desired convergence of $10^{-8}$ and conclusions about the runs may be suspect. Only direct experiments with the system will confirm or deny this.

The First set of HEATING5 Calculations

Table 2 summarizes some of the factors associated with the first set of computations:

Brass Envelop - Run 2 applies to the original pipe tester design which called for a brass envelop. Convergence exceeded $5 \times 10^{-6}$ after 2110 1terations, but the $62 / G 1$ ratio of 1.05 yielded cold ends and a $\lambda$ (midplane) $725 \%$ above the expected

(0.02). This design was abandoned for for a stainless steel envelop.

Stainless Steel Envelop 1 - Three G2/Gl ratios were studied $2: 1$ (Runs 9, 12, 20), 4:1 (Runs 10,13) and $3: 1$ (Runs 16, 18). In the 2:1 case after 6300 iterations convergence approached $10^{-7}$, but $\lambda$ (midplane) was still $8 \%$ high due to the ends running cold $T_{0}-T_{1.5}=129^{\circ} \mathrm{F}$. In the $4: 1$ case, 4200 iterations pro- 
duced a poor convergence, but the hot ends were driving $\lambda$ (midplane) down even at $10^{-5}$ convergence. The $3: 1$ case after 4200 iterations obtained $10^{-6}$ convergence, but the ends were still hot and $\lambda$ (midplane) was 3.48 low.

Stainless Steel Envelop 2 - By changing the stainless steel $\lambda$ from 9.4 to 2.4 a thinner envelop was approximated and tests run at a G2/GI ratio of $2: 1$ and $1.5: 1$. The $2: 1$ ratio converged to $10^{-7}$ after 4200 iterations, but yielded hot ends and a $\lambda$ (midplane) 2.38 low. The $1.5: 1$ ratio initiated at $700^{\circ} \mathrm{F}$, obtained a poorer convergence. $\left(3.4 \times 10^{-6}\right)$ after 4200 iterations, but yielded cold ends and a $\lambda$ (midplane) 68 high. Initiating the $1.5: 1$ ratio system at $2500^{\circ} \mathrm{F}$ yielded a similar $\lambda$ (midplane) result $8 \%$ high with poorer convergence.

\section{The second set of HEATING5 Calculations}

This first set of calculations was so slow to converge that the original pipe tester was remapped slightly: More nodes were added near the midplane, all convection at internal gaps was replaced with radiation interfaces, the web connecting the stainless envelop guard to the main region was reduced in $\lambda(9.4$ to 0.94$)$ to reduce end losses from the main envelop. A second set of calculations were initiated and these are summarized in Table 3 .

Stainless steel Envelop 3 - This system includes a lower $\lambda$ for the SS $(2.4)$ and $\lambda$ redustion of the web connector $(0.94)$. Three G2/Gl power density ratios were studied: $2.5: 1$ (runs 26 , 28,31 ), $2: 1$ (Runs $25,27,30$ ) and $1.5: 1$ (Runs 29, 31). The 2.5:1 case converged to $10^{-6}$ after 6300 iterations and yielded . extremely hot ends $\left(\Delta \mathrm{T} \sim 455^{\circ} \mathrm{F}\right)$ which yielded a $\lambda$ (midplane) too 
low by $6.1 \%$. The $2: 1$ case is very similar to the $2.5: 1$ case, but the ends are not quite as hot and $\lambda$ (midplane) is low by only 2.18 . The $1.5: 1$ case yielded slightly cold ends $\left(150^{\circ} \mathrm{F}\right)$ and a $\lambda$ (midplane) too high by $(\sim 2.7 \%)$ at a convergence of $\left.4 \times 10^{-8}\right)$.

These latter two cases suggest a $G 2 / G 1$ ratio of $1.1: 1$ "might yield balanced ends. For a G2/Gl ratio of $1.8: 1$ (Runs $34,36,38$ ) and end balance was within $30^{\circ} \mathrm{F}$ and the midplane $\lambda$ was 0.38 low which suggests a further lowering of $G 2$ would be useful. Calculations suggest control of the 1.5 foot stainless steel web temperature to that of the stainless steel midplane temperature would produce correct thermal conductivity values.

\section{TENTATIVE CONCLUSIONS}

1. The HEATING5 model of the York Research Pipe Tester shows the calculated specimen thermal conductivity agrees. with the input specimen thermal conductivity to $0.3 \%$ for a $30^{\circ} \mathrm{F}$ temperature difference between the stainless steel midpoint and web section. A $3 \%$ difference was noted for a $150 \%$ temperature difference. I'his is a very favorable result. and suggests a useful operational control prescription.

2. HEATINGS modeling of other pipe testers is a desirable goal. 


\section{REFERENCES}

1. Private communication, A.D. Lampert and A.H. Laube, York Research Corporation, to D.L. MCElroy and J.P. Moore, Dec. 14; 1976 .

2. W.D. Turner, D.C. Elrod and I.I: Siman-Tov, HEATING5-An IBM 360 Heat conduction Program, ORNL/CSD/TM-15 (1977).

3.-10. Save for material properties references. 
Table 1. Temperature Independent Thermal Conductivity of Various Pipe Tester Materials

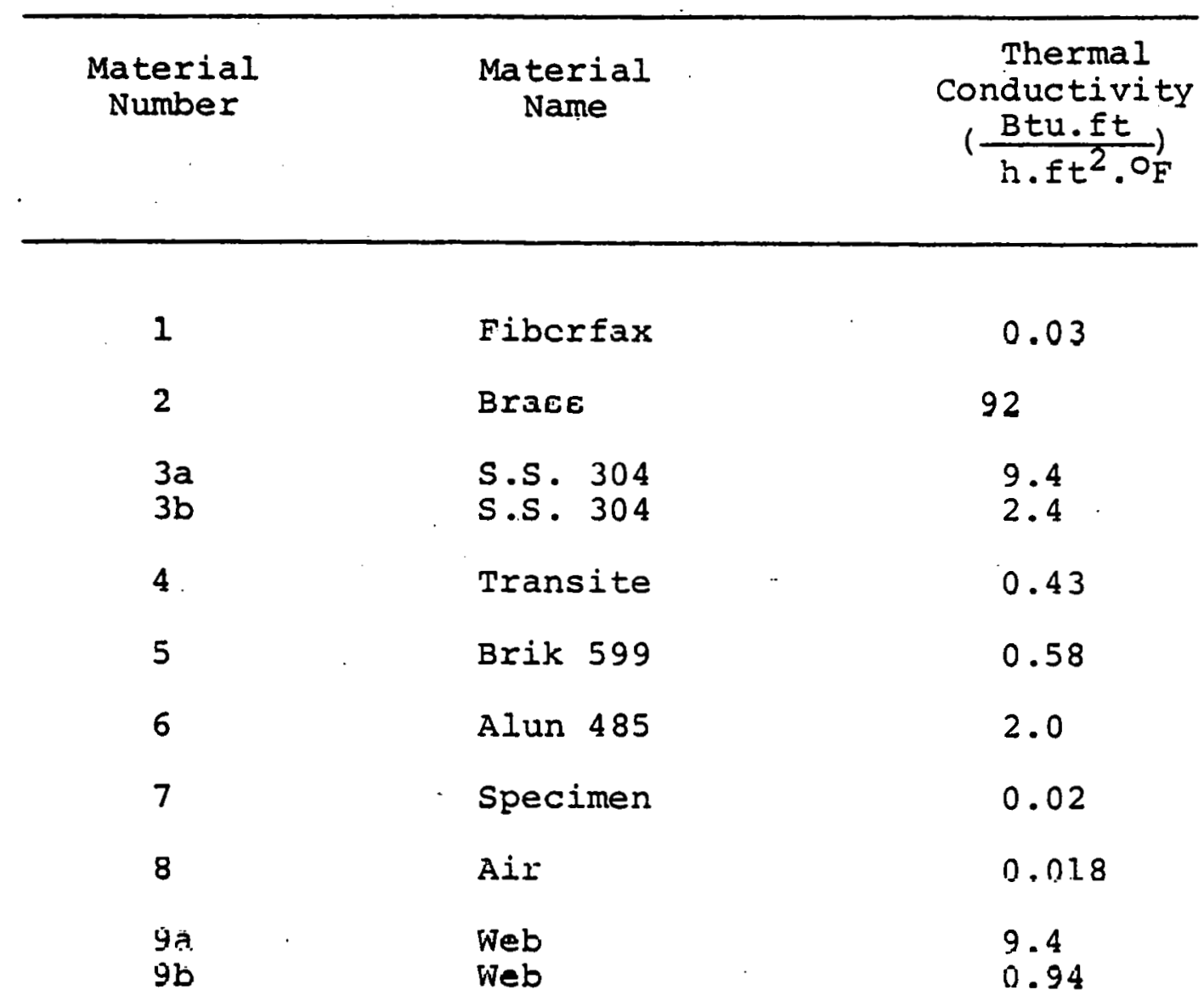


Table 2. Summary of the First Set of HEATING5 Calculations

\begin{tabular}{|c|c|c|c|c|c|c|c|}
\hline Run & $\frac{G 2}{61}$ & $\begin{array}{l}\text { Envelop } \\
(\lambda)^{\star}\end{array}$ & Convergence & $\begin{array}{l}T_{\text {Hean }} . \\
\left({ }^{\circ} \mathrm{F}\right)\end{array}$ & $\begin{array}{c}\lambda * \\
\text { Midplane }\end{array}$ & $\frac{{ }^{\lambda} \mathrm{Ca} \mathrm{1c}}{0.02} \times 100$ & $\begin{array}{l}\text { Axinl } \\
\text { Envelop } \Delta T \\
\left.T_{0}{ }^{\circ} \mathrm{F}\right)\end{array}$ \\
\hline 2 & $\frac{120,000}{114,400}$ & Brags. & $4.7 \times 10^{-6}$ & 493 & 0.1450 & 725 & 42 \\
\hline 9 & $\frac{100,000}{50,000}$ & $\begin{array}{l}\text { S.S. } \\
(9: 4)\end{array}$ & $3.0 \times 10^{-6}$ & 1063 & 0.0261 & 130 & 7.58 \\
\hline 12 & & & $4.1 \times 10^{-7}$ & 1239 & 0.0220 & 110 & 119.0 \\
\hline 20 & & & $2.5 \times 10^{-7}$ & 1257 & 0.0217 & 108 & 129 \\
\hline 10 & $\frac{200,000}{50,000}$ & $\begin{array}{l}9,5 \\
(9.4)\end{array}$ & $2.5 \times 10^{-11}$ & 486 & 0.0646 & 323 & -488.35 \\
\hline 13 & & & $4.3 \times 10^{-5}$ & 131,4 & 0.0202 & 101 & -603.6 \\
\hline 16 & $\frac{150,000}{50,000}$ & $\begin{array}{l}\text { S.s. } \\
(9.4)\end{array}$ & $2.5 \times 10^{-5}$ & 1227 & 0.0222 & 111 & \\
\hline 18 & - & & $1 \times 10^{-6}$ & 1397 & 0.0193 & 96.6 & -160.9 \\
\hline 17 & $\frac{1.00,000}{50,000}$ & $\begin{array}{l}\text { S.s, } \\
(2.4)\end{array}$ & $4.2 \times 10^{-4}$ & 1371 & 0.0197 & 98.6 & -152 \\
\hline 19 & & . & $9.94 \times 10^{-8}$ & 1383 & 0.0195 & 97.7 & -144.5 \\
\hline 21 & $\frac{75,000}{50,000}$ & $\begin{array}{l}3.5 \\
(2.4)\end{array}$ & $4.6 \times 10^{-6}$ & 1269 & 0.0214 & 107 & 114.8 \\
\hline 23 & & & $3,4 \times 10^{-6}$ & 1281 & 0.0212 & 106 & 122.9 \\
\hline 22 & & $\begin{array}{l}\text { s.s. } \\
(2.4) \\
t_{0}=2500\end{array}$ & $3.9 \times 10^{-5}$ & 1220 & 0.0224 & 112 & $-15,8$ \\
\hline 24 & & & $7.3 \times 10^{-6}$ & 1253 & 0.0217 & 108 & 54.96 \\
\hline
\end{tabular}

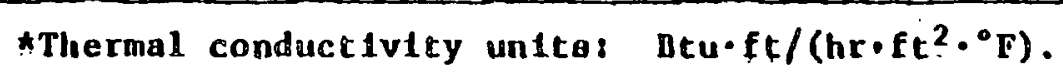


Table 3. Sumnary o₹ Second Set of HEATING5 Ealculations

\begin{tabular}{|c|c|c|c|c|c|c|c|c|}
\hline Run & $\frac{G 2}{G !}$ & $\begin{array}{l}\text { Envelop } \\
(\lambda)^{\star}\end{array}$ & Convergence & $\mathrm{T}_{\left({ }^{\circ} \mathrm{F}\right)}$ & $\operatorname{MLd}^{\star}{ }_{\text {LEne }}$ & $\frac{{ }^{\lambda} \mathrm{Ca1c}}{0.02} \times 1$ & 100 & $\begin{array}{l}\text { Axial } \Delta \mathrm{T} \\
\text { Envelop } \\
\mathrm{T}_{0} \mathrm{C}^{\circ} \mathrm{T}^{1.5}\end{array}$ \\
\hline 26 & $\frac{125,000}{50,000}$ & $\begin{array}{l}\text { s.s. } \\
(2.1)\end{array}$ & $1.7 \times 10^{-5}$ & 1325 & $0.0 \dot{2} 22$ & 111.2 & & -613 \\
\hline 28 & & & $4.0 \times 10^{-6}$ & 1481 & 0.0197 & 98.5 & & -505 \\
\hline 31. & & & $1 \times 10^{-6}$ & 1547 & 0.0188 & 93.9 & . & -455 \\
\hline 25 & $\frac{1.00,000}{50,000}$ & $\begin{array}{l}\text { S.S. } \\
(2.4)\end{array}$ & $3,3 \times 10^{-5}$ & 1453 & 0.02001 & 100.5 & & -177 \\
\hline 27 & & & $1.1 \times 10^{-6}$ & 1475 & 0.01976 & 98.8 & & -160 \\
\hline 30 & & & $3.7 \times 10^{-7}$ & 1487 & 0.01959 & 97.9 & $\cdot$ & -151 \\
\hline 29 & $\frac{75,000}{50,000}$ & $\begin{array}{l}\text { s.s. } \\
(2.4)\end{array}$ & $9.2 \times 10^{-6}$ & 1232 & $0.02: 10$ & 120,2 & & +14.5 \\
\hline 32 & & & $1.3 \times 10^{-5}$ & 1385 & 0.02116 & 105.8 &. & +122.4 \\
\hline 33 & & & $4 \times 10^{-8}$ & 1423 & 0.02055 & 102.76 & & +1.50 \\
\hline 34 & $\frac{90,000}{50,000}$. & $\begin{array}{l}\text { S.S. } \\
(2.4)\end{array}$ & $2.3 \times 10^{-5}$ & 1326 & 0.02220 & 111.00 & $\ddots$ & -126 \\
\hline 36 & & & $1.7 \times 10^{-6}$ & 1460 & 0.01998 & 99.89 & & -31.8 \\
\hline 38 & & & $5 \times 10^{-\theta}$ & 1463 & 0.01094 & 99.72 & & -30 \\
\hline
\end{tabular}

*Thernal copductivity units, $\mathrm{Btu} \cdot \mathrm{ft} /\left(\mathrm{hr} \cdot \mathrm{ft}^{2}{ }^{\circ} \mathrm{F}\right)$. 